\title{
Sandwich Structures for Energy Absorption Applications: A Review
}

\author{
Faris Tarlochan (1)
}

check for

updates

Citation: Tarlochan, F. Sandwich Structures for Energy Absorption Applications: A Review. Materials 2021, 14, 4731. https://doi.org/ $10.3390 / \mathrm{ma} 14164731$

Academic Editor: Aase Reyes

Received: 26 July 2021

Accepted: 19 August 2021

Published: 22 August 2021

Publisher's Note: MDPI stays neutral with regard to jurisdictional claims in published maps and institutional affiliations.

Copyright: (C) 2021 by the author. Licensee MDPI, Basel, Switzerland. This article is an open access article distributed under the terms and conditions of the Creative Commons Attribution (CC BY) license (https:/ / creativecommons.org/licenses/by/ $4.0 /)$.
Department of Mechanical and Industrial Engineering, Qatar University, Doha 2713, Qatar; faris.tarlochan@qu.edu.qa

\begin{abstract}
It is crucial that proper engineering structures are designed as energy absorbers for high dynamic loading situations, such as accidents, blasts, or impacts. The role of such structures is to absorb the high kinetic energy as strain energy through irreversible deformation of the structure. Many types of energy absorbers were designed for different dynamic high strain rate applications. One of these structures are sandwich structures. The aim of this review paper is to provide a general review on the type of sandwich structures that have been designed as energy absorbers and their performance in crashworthiness and blast related applications. The focus is on the type of core structures being used, namely foam and architected cores. It was found from the review that sandwich structures are viable candidates for such applications not only because of their light weight, but also due to the high-energy absorption capabilities. The work presented in this review paper shows that the data from the literature on this topic are vast and do not converge to any particular sandwich structure design. This presents the potential future research direction in designing sandwich structures, which have wider application at different scales.
\end{abstract}

Keywords: sandwich structure; foam; honeycomb; auxetic structure; architected core; crashworthiness; blast; impact

\section{Introduction}

Engineering structures are designed and developed for many applications, such as load bearing (fatigue or static), high-pressure containment, safety, energy absorption, etc. These structures come in various design configurations, geometries, materials, loading conditions, physical constraints, etc., each one unique to the type of application. The focus of this review paper is to look at engineering structures designed primarily for energy absorption applications, particularly sandwich structures, due to the current engineering requirements for lightweight structures [1]. Energy absorbing structures are designed primarily to absorb energy during a dynamic event, such as a high strain rate event like an impact (due to collisions) or blast [2-9]. Other areas such as the cargo/goods packaging sectors also require structures that are able to absorb "impact" energy during handling and transportation. This paper, however, is focusing just on structures used for absorbing energy during high strain rate events, in particular crashworthiness and blast related. The motivation of this paper is to consolidate findings by researchers in the area of using sandwich structures as energy absorbers in high dynamic events and to identify future research directions to enhance/strengthen this area of research (applications to crashworthiness and blast related). Crashworthiness is defined as the extent to which a vehicle is able to protect its occupants in the event of a collision or accident. In the area of blast applications, sacrificial or cladding structures are designed to absorb the energy in the event of a blast to protect the primary structure due to the blast wave and perforations due to blast projectiles like shrapnel. Both applications, crashworthiness and blast resistant, require structures that are able to absorb energy to protect people or cargo from serious damage or injuries. In such applications, energy absorbers are designed to absorb the change in kinetic energy (during an accident or blast) into strain energy that 
is then used to deform the energy absorber. Some of the parameters used for analysis are energy absorption $(E A)$, specific energy absorption $(S E A)$, and mean crush force $\left(P_{m}\right)$. The literature documents various designs of energy absorbers based on different materials, loadings, and geometries, similar to those reported in [2-9]. Graphical details of such applications are depicted in Figure 1. In Figure 1a, $d_{\max }$ represents the maximum crushed distance before densification starts, or where the deformation (crushing) stops, whereas $m$ represents the crushed mass.

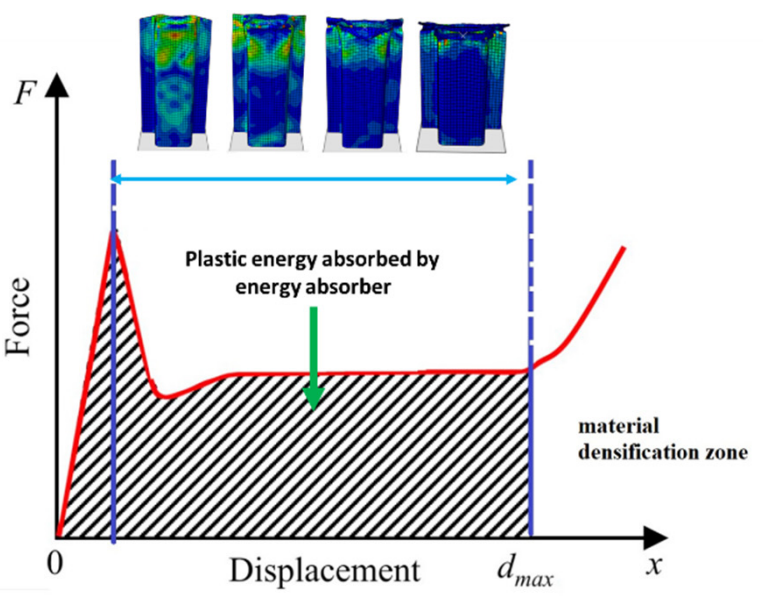

$$
\begin{aligned}
& \text { Energy absorbed }(\mathrm{J}): \\
& E A(d)=\int_{0}^{d \max } F(x) d x
\end{aligned}
$$

Specific energy absorbed $(\mathrm{J} / \mathrm{g})$ :

$S E A(d)=\frac{E A(d)}{m}$

\section{Mean crush force $(\mathrm{N})$ :}

$P_{m}=\frac{E A(d)}{d_{\max }}=\frac{\int_{0}^{d_{\max }} F(x) d x}{d_{\max }}$

(a)
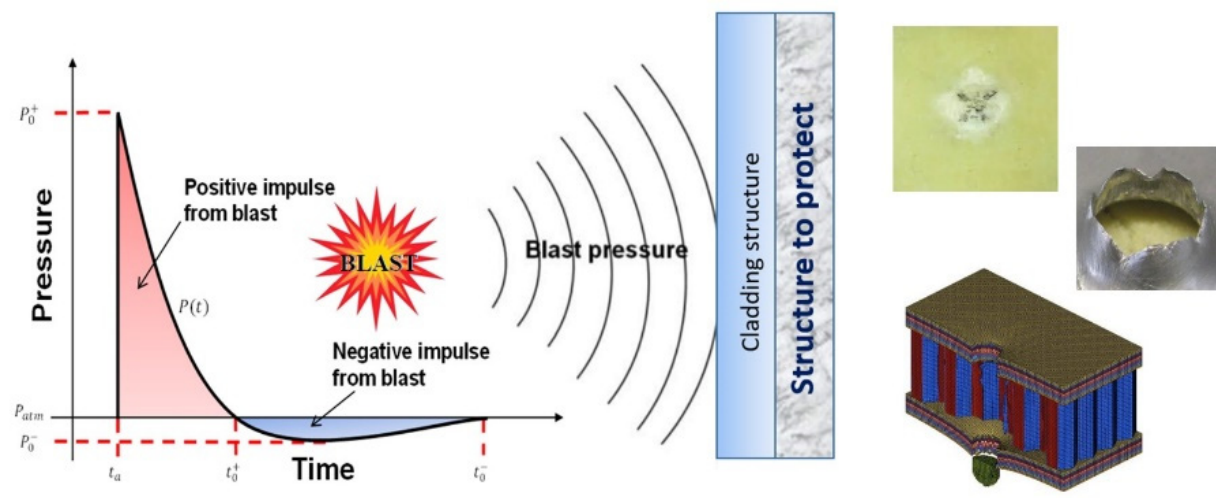

(b)

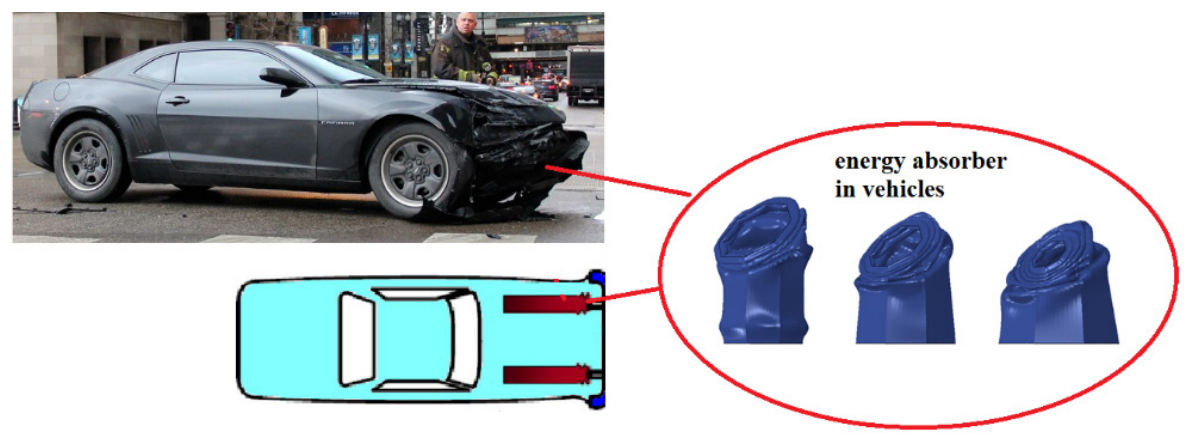

(c)

Figure 1. (a) General energy absorption through deformation of energy absorbers, (b) energy absorbers used as cladding structures for blast resistant applications and. (c) energy absorbers used in vehicle safety. [partial image source: "Aftermath of Car Crash on Randolph at Michigan, 21 January 2015" by danxoneil is licensed under CC BY 2.0]. 
With reference to Figure $1 b$, when a detonation takes place, a huge amount of energy is released in an unconfined medium, giving rise to blast wave expanding in all directions. At some fixed point away from the point of blast, there is a rapid peak in pressure followed by a rapid decay. The time the shock arrives here is called time or arrival of shock and is denoted as $t_{a}$. Sometimes, the static pressure will fall below atmospheric but will eventually equilibrate (negative pulse). However, this depends on the conditions of blast and the distance from the blast location. The rise in pressure is due to the shock wave moving forward from the point of blast. Positive pulse duration is the time when the pressure is positive and this helps to define the positive impulse, which is the area under the curve. For blast mitigation applications, this positive impulse is used for designing the energy absorbers.

Among the common engineering structures used for energy absorption application are sandwich structures. A typical sandwich structure consists of two face sheets separated by a lightweight thick core structure such as foams or honeycombs. Lightweight sandwich structures are used extensively in aerospace, marine, and automotive industries due to the high flexural stiffness-to-weight ratio and excellent energy absorption capability [10]. The idea of sandwich structures for energy absorption applications is actually not a new concept. Rather, they are inspired by nature, e.g., the human skull that comprises two layers of dense cortical bone separated by a spongy bone (core-cancellous bone) to protect the brain from small impacts (Figure 2) [11]. Having this in mind, and the requirement for lightweight materials, the paper will discuss works related to sandwich structures used for potential energy absorption related applications. Since the principal energy absorption is due to the deformation of the sandwich core structure [12], the paper will be organized based on two core structure configurations: (a) cellular foam cores and (b) architected cores.

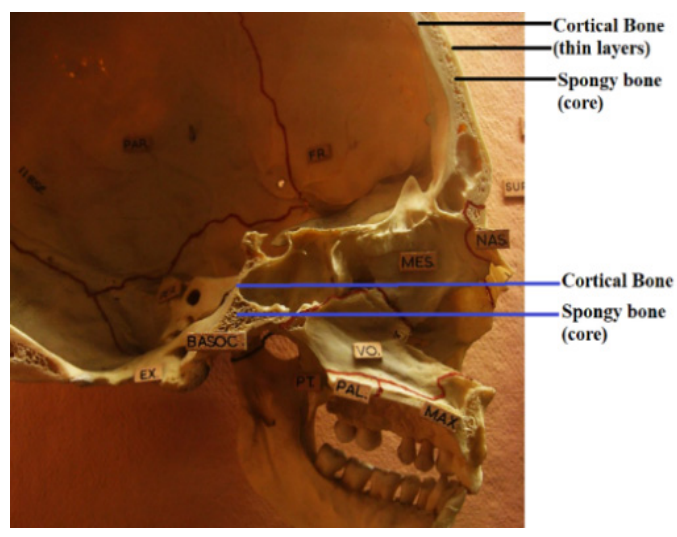

(a)

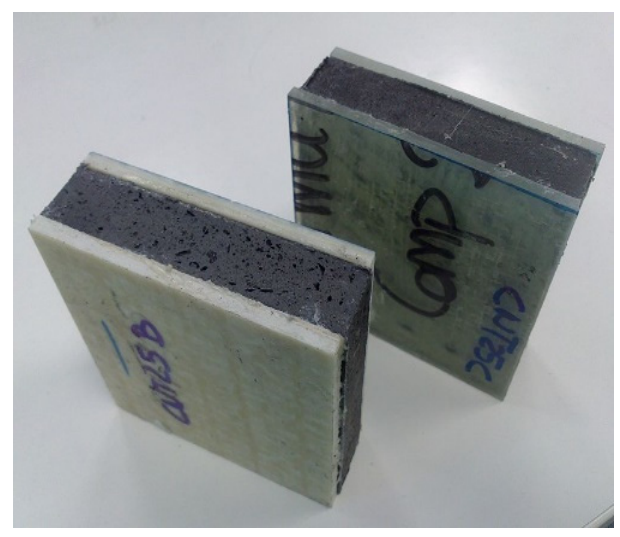

(b)

Figure 2. (a) Human skull a nature's design of sandwich structure for energy absorption. (Source of image: "Human Skull" by Quasimondo is licensed under CC BY-NC 2.0) (b) Example of sandwich panel (Source of image: "NANOCORE sandwich panel with MWCTs" by JavierACCIONA is licensed under CC BY-NC 3.0).

\section{Sandwich Structures for Energy Absorption}

This section will contain the literature review on sandwich structures used as energy absorbers. In sandwich structures, the type of high strain rate application will determine the way a sandwich structure is designed. In blast wave/crashworthiness applications, if the sandwich panel is designed to be compressed flatwise, the core plays a crucial role in the energy absorption, compared to the face sheets. However, if the panels are designed for edgewise compression, both the face sheets and core play a role in the energy absorption. For perforation applications due to blast, there is penetration of the structure due to some projectiles. Here, again, the combination of the face sheets and core play a vital role in improving impact resistance. In all the above applications, the failure mechanism of the sandwich structure/panel is a crucial element in the energy absorption capabilities of a 
structure. Local buckling of core cell wall structures (foam or architecture cores), core shearing, indentation, face sheet yielding, wrinkling, and interlaminar failure of face sheets are some of the failure mechanisms observed in during these applications. The review will be broken down into two sections based on the type of core used: (1) foam cores and (2) architected cores.

\subsection{Cellular Foam Core Structure}

Foams are lightweight structures that can absorb a good amount of energy when stressed to their plateau region (plastic deformation) in the stress-strain diagram, as described by Gibson and Ashby [13]. A typical constant plateau is about $60-70 \%$ of the total strain value [13]. The beauty of foams is that their properties are heavily dependent on their density, hence allowing designers the capability to develop foams unique for its applications $[14,15]$. The foams are fabricated as open cell or closed cell structures, where the former leads to a lighter structure because the cells structures in the foam are not completely encapsulated. In the literature, significant results have been presented concerning the ability of metallic and polymeric foams as standalone structures for energy absorption applications. This review paper will only focus on sandwich structures that utilizes these foams as structural cores.

\subsubsection{Polymeric Foam Core}

Some sandwich structure designs utilize polymeric foams as the core material due to the cost and ease of fabrication compared to metallic foams. Table 1 details a summary of some of the related applications of such sandwich structures. The typical applications are for low velocity impact (perforation), shock wave, and crashworthiness applications. For sandwich structure face sheets, typical materials used are either metals or fiber composites. For the core, various polymers have been used, such as polyvinyl chloride (PVC), polyethylenimine (PEI), polystyrene (PS), polyurethane (PU), polymethacrylimide (PMI), and styrene acrylonitrile (SAN), to name a few. Some of the key findings are as follows:

- Graded polymeric cores (varying densities) are better than uniform density cores

- Different polymer cores perform differently

- The type of boundary conditions used affected the blast mitigation strategy

- Failure mechanisms of the composite face sheets and core play a vital role in the energy absorption capability

- Parametric design is crucial to optimize the sandwich structure for energy absorption based on application type

- The type of blast (near vs. far field) creates different responses on the sandwich panel

- Sandwich structures used for crashworthiness related applications/testing conditions demonstrated progressive crushing

Table 1. Sandwich structure with polymeric foam core.

\begin{tabular}{|c|c|c|c|}
\hline Sandwich Construction & Loading/Application & Summary of Findings & Reference \\
\hline $\begin{array}{l}\text { PVC, cross-linked PVC and PEI foams were } \\
\text { bonded together to produce a three layer } \\
\text { core bonded with carbon fibre face sheets }\end{array}$ & $\begin{array}{l}\text { Low velocity Impact } \\
\text { (perforation-experiment) }\end{array}$ & $\begin{array}{c}\text { Improved perforation resistance was achieved } \\
\text { when the highly dense layer was attached } \\
\text { to the top skin. }\end{array}$ & [16] \\
\hline $\begin{array}{l}\text { E-Glass fiber composite face sheets } \\
\text { with graded styrene foam cores } \\
\text { different densities }\end{array}$ & $\begin{array}{l}\text { Shock wave loading } \\
\text { (blast-experiment) }\end{array}$ & $\begin{array}{c}\text { The low / middle/high density foam } \\
\text { configuration had better energy absorption } \\
\text { capabilities compared to other configurations } \\
\text { of the foam densities. }\end{array}$ & [17] \\
\hline $\begin{array}{l}\text { Sandwich panel consisting of E-glass } \\
\text { fiber composite face sheets and H100 } \\
\text { PVC foam core }\end{array}$ & $\begin{array}{c}\text { Blast loading } \\
\text { (analytical solution) }\end{array}$ & $\begin{array}{l}\text { Two phases of deformation were identified: (a) } \\
\text { core crushing during through-thickness wave } \\
\text { propagation and (b) global panel bending/shear } \\
\text { during transverse shear wave propagation }\end{array}$ & [18] \\
\hline $\begin{array}{l}\text { Sandwich composites made of E-glass } \\
\text { fiber composite face sheets and graded } \\
\text { Corecell }{ }^{\mathrm{TM}} \text { A-series foam }\end{array}$ & $\begin{array}{l}\text { Shock wave loading } \\
\text { (blast-experiment) }\end{array}$ & $\begin{array}{l}\text { Designing the foam cores to be graded } \\
\text { monotonically, helps improve blast resistant } \\
\text { performance. At higher temperatures, the failure } \\
\text { mechanism of the cores differed to the lower } \\
\text { temperatures. }\end{array}$ & {$[19,20]$} \\
\hline
\end{tabular}


Table 1. Cont.

\begin{tabular}{|c|c|c|c|}
\hline Sandwich Construction & Loading/Application & Summary of Findings & Reference \\
\hline $\begin{array}{l}\text { Sandwich material with a soft layer (PU) in } \\
\text { between woven composite skins (EVE) }\end{array}$ & $\begin{array}{l}\text { Shock wave loading } \\
\text { (blast-experiment) }\end{array}$ & $\begin{array}{l}\text { Sandwich panels had better blast resistance } \\
\text { performance than composite plates. }\end{array}$ & [21] \\
\hline $\begin{array}{l}\text { Sandwich panels comprising E-glass fibre } \\
\text { reinforced vinyl ester face sheets and } \\
\text { closed cell PVC foam cores }\end{array}$ & $\begin{array}{c}\text { Blast loading } \\
\text { (blast-experiment) }\end{array}$ & $\begin{array}{l}\text { Face-sheet delamination and fiber fracture along } \\
\text { with core compression were significant energy } \\
\text { absorption modes. For low core densities, the face } \\
\text { sheets absorbed more energy due to the blast. }\end{array}$ & {$[22]$} \\
\hline $\begin{array}{l}\text { Glass fiber reinforced sandwich panels } \\
\text { with PVC, PMI and SAN foam cores }\end{array}$ & $\begin{array}{l}\text { Air blast testing } \\
\text { (blast-experiment) }\end{array}$ & $\begin{array}{l}\text { All three type of polymer cores are effective in } \\
\text { improving blast resistant where the SAN core was } \\
\text { the most blast tolerant. It was also found that by } \\
\text { grading the core densities, a smoother back } \\
\text { face-sheet deflection profile was achievable. }\end{array}$ & {$[23]$} \\
\hline $\begin{array}{l}\text { (1) E-glass fabric face sheets with balsa } \\
\text { wood core, ( } 2) \text { E-glass fabric face sheets } \\
\text { with PVC foam core, ( } 2 \text { ) E-glass fabric face } \\
\text { sheets with balsa wood core, }(2)\end{array}$ & $\begin{array}{l}\text { Large air blast testing } \\
\text { (blast-experiment) }\end{array}$ & $\begin{array}{l}\text { Failure mode maps were developed to provide } \\
\text { insights on how panel failure depends on the key } \\
\text { variables during a blast event }\end{array}$ & [24] \\
\hline $\begin{array}{l}\text { E-glass face sheets and a Styrene } \\
\text { Acrylo-Nitrile (SAN) foam core }\end{array}$ & $\begin{array}{l}\text { (a) Primary: a high velocity } \\
\text { projectile or a low velocity } \\
\text { drop weigh followed by } \\
\text { (b) Secondary: blast loading } \\
\text { (impact/blast-experiment) }\end{array}$ & $\begin{array}{l}\text { The damage due to low velocity drop weights } \\
\text { had the greatest detrimental effect on the blast } \\
\text { performance of the sandwich composites. This is } \\
\text { due to the initial failure of the panels, which } \\
\text { involves debonding of the face sheets and shear } \\
\text { cracking of the core. }\end{array}$ & [25] \\
\hline $\begin{array}{l}\text { 3-D woven } 3 W E A V E{ }^{\circledR} \text { E-glass fiber } \\
\text { composites skin preforms integrally } \\
\text { stitched to polyisocyanurate } \\
\text { TRYMERTM 200L foam core }\end{array}$ & $\begin{array}{l}\text { Shock wave loading } \\
\text { (blast-experiment) }\end{array}$ & $\begin{array}{l}\text { Through-thickness stitching with foam core } \\
\text { increases the shock wave resistance and damage } \\
\text { tolerance. It was also found that the prominent } \\
\text { damage mechanism differs for unstitched to } \\
\text { stitched sandwiches, where increasing stitching } \\
\text { density changes the damage mechanism. }\end{array}$ & [26] \\
\hline $\begin{array}{l}\text { E-glass quadriaxial skins with } \\
\text { SAN foam core (Large panels) }\end{array}$ & $\begin{array}{l}\text { Air Blast loading } \\
\text { (blast experiment) }\end{array}$ & $\begin{array}{l}\text { The type of boundary conditions (type and } \\
\text { location) plays and important role in blast } \\
\text { mitigation applications. }\end{array}$ & {$[27,28]$} \\
\hline $\begin{array}{l}\text { Analytical model of metallic sandwich } \\
\text { with soft and hard cores }\end{array}$ & $\begin{array}{l}\text { Water Blast loading } \\
\text { (Blast-analytical and simulation) }\end{array}$ & $\begin{array}{l}\text { Sandwich plates with stiff cores imparted higher } \\
\text { blast impulses compared to those with softer } \\
\text { cores and equivalent areal mass }\end{array}$ & [29] \\
\hline $\begin{array}{l}\text { Sandwich panels with Divinycell } \mathrm{H}-100 \\
\text { PVC foam and glass fiber epoxy face sheets }\end{array}$ & $\begin{array}{c}\text { Water Blast loading } \\
\text { (Shock tube)(blast experiment) }\end{array}$ & $\begin{array}{l}\text { Sandwich panels with face sheet-thickness- } \\
\text { to-core-thickness ratios between } 0.15 \text { and } \\
0.4 \text { provided the best blast resistance design }\end{array}$ & {$[30]$} \\
\hline $\begin{array}{l}\text { Sandwich composites made of E-Glass } \\
\text { Vi-nyl-Ester (EVE) face sheets and graded } \\
\text { Core-cell }{ }^{\mathrm{TM}} \text { A-series foam }\end{array}$ & $\begin{array}{l}\text { Air blast loading } \\
\text { (blast experiment) }\end{array}$ & $\begin{array}{l}\text { Due to the buckling of the face sheet (in plane } \\
\text { compressive loading), the blast resistance } \\
\text { efficiency reduced, indicating to some } \\
\text { extend the face sheets play an important } \\
\text { role in blast resistant designs. }\end{array}$ & {$[31]$} \\
\hline $\begin{array}{l}\text { Foam-core, curved composite } \\
\text { sandwich pane }\end{array}$ & $\begin{array}{c}\text { Air Blast loading } \\
\text { (Blast-analytical and simulation) }\end{array}$ & $\begin{array}{l}\text { Blast resistance increases when the sandwich } \\
\text { cores are allowed to undergo plastic deformation. } \\
\text { Besides this, it was found that dense foam cores } \\
\text { did not increase the blast resistance but } \\
\text { allowed face sheets to fracture while the } \\
\text { core remained elastic. }\end{array}$ & {$[32]$} \\
\hline $\begin{array}{c}\text { Double-curvature, } \\
\text { sandwich shallow shell with PVC } \\
\text { foam (face sheet E-Glass/Vinyl } \\
\text { Ester Woven Roving) }\end{array}$ & $\begin{array}{c}\text { Air Blast loading } \\
\text { (Blast-analytical model) }\end{array}$ & $\begin{array}{l}\text { (1) Blast resistance increases as the panel } \\
\text { curvature ratio decreases because shells, } \\
\text { (2) blast resistance of isotropic core is higher } \\
\text { than transversely isotropic core as the shell } \\
\text { radius of curvature decreased. }\end{array}$ & [33] \\
\hline $\begin{array}{l}\text { Sandwich panel: nano-scale core-shell } \\
\text { rubber (CSR) toughened E-glass } \\
\text { Vinyl-Ester face-sheets and Corecell A500 }\end{array}$ & $\begin{array}{l}\text { High pressure shock } \\
\text { (blast-experiment) }\end{array}$ & $\begin{array}{l}\text { CSR particles helps in dispersing the initial shock } \\
\text { wave loading, thus improving the overall blast } \\
\text { resistance of the structure }\end{array}$ & [34] \\
\hline $\begin{array}{l}\text { Sandwich panels face sheets made up from } \\
\text { glass and carbon fibers, with PVC foam core. }\end{array}$ & $\begin{array}{l}\text { Air Blast loading } \\
\text { (blast-experiment) }\end{array}$ & $\begin{array}{l}\text { Under large-scale blast loading where the load is } \\
\text { almost uniform across the panel, the type of face } \\
\text { sheet material does not influence much on the } \\
\text { panel deformation. }\end{array}$ & {$[35]$} \\
\hline $\begin{array}{l}\text { Sandwich structure consists of glass fiber } \\
\text { composites as face sheets, and core is rigid } \\
\text { polyurethane }\end{array}$ & $\begin{array}{l}\text { Gas gun projectile impact } \\
\text { (perforation- experimental) }\end{array}$ & $\begin{array}{l}\text { The density of the core material plays an } \\
\text { important role in ballistic performance } \\
\text { requirements. Neither too rigid nor too soft cores } \\
\text { are desirable. This is related to the foam's cell } \\
\text { wall thickness and strut. }\end{array}$ & {$[36]$} \\
\hline $\begin{array}{l}\text { Sandwich structures face sheets made from } \\
\text { glass fiber, core is polystyrene foam }\end{array}$ & $\begin{array}{c}\text { Compression Test } \\
\text { (Crashworthiness-experimental) }\end{array}$ & $\begin{array}{l}\text { Sandwich structure collapsed in a progressive manner } \\
\text { exhibiting high-energy absorption capabilities. }\end{array}$ & [37] \\
\hline $\begin{array}{c}\text { Sandwich structures face sheets made from } \\
\text { glass and carbon fiber composites, core is } \\
\text { polystyrene foam }\end{array}$ & $\begin{array}{l}\text { Compression Test } \\
\text { (Crashworthiness-experimental) }\end{array}$ & $\begin{array}{l}\text { Four failure modes were observed with the primary } \\
\text { mode of failure was progressive crushing due to } \\
\text { the foam as core structure. The optimized design } \\
\text { had a very good specific energy absorption capability. }\end{array}$ & [38] \\
\hline
\end{tabular}




\subsubsection{Metallic Foam Core}

For higher energy absorption performance, sandwich structures designed with metallic foams are used. Table 2 details a summary of some of the related applications of such sandwich structures. The typical applications reported in the literature are for low velocity impact (perforation), shock wave, and crashworthiness applications. For sandwich structure face sheets, typical materials used are either metals (stainless steel/aluminum) or fiber composites. For the core, the most common foam material used was aluminum. Some of the key findings are as follows:

- Graded metallic cores are better than uniform density cores.

- Failure mechanisms of the face sheets and core play a vital role in the energy absorption capability.

- Parametric design is crucial to optimize the sandwich structure for energy absorption.

- For perforation applications, it was found that the sandwich panels performed poorly compared to the monolithic aluminium panel.

- Sandwich structures used for crashworthiness related applications/testing conditions demonstrated progressive crushing.

- The blast resistance of the sandwich panels comprised of the composite face sheets outperformed the metallic counterparts.

- Strain rate of the foam core is important in defining the crushing behavior which is linked to the energy absorption capabilities.

Table 2. Sandwich structure with metallic foam core.

\begin{tabular}{|c|c|c|c|}
\hline Sandwich Construction & Loading/Application & Summary of Findings & Reference \\
\hline $\begin{array}{l}\text { Spherical shell sandwich made from } \\
\text { aluminum metallic foam cored with } \\
\text { varying densities with outer and inner } \\
\text { face sheet made from aluminum }\end{array}$ & $\begin{array}{l}\text { Inner blast loading-from inner } \\
\text { center of the structure } \\
\text { (blast-simulation) }\end{array}$ & $\begin{array}{l}\text { The arrangement of core foam density play } \\
\text { an important role in optimizing the blast } \\
\text { resistant response }\end{array}$ & [39] \\
\hline $\begin{array}{l}\text { Square sandwich panels made up from } \\
\text { aluminum alloy face-sheets and a layered } \\
\text { gradient aluminium foam core }\end{array}$ & $\begin{array}{l}\text { Air-blast loading } \\
\text { (blast-simulation) }\end{array}$ & $\begin{array}{c}\text { Blast resistant efficiency depends on how the } \\
\text { layered gradient foam cores are arranged. Besides } \\
\text { this thickness of the face sheet has little influence } \\
\text { on the blast resistance. }\end{array}$ & [40] \\
\hline $\begin{array}{l}\text { Three types of face sheet materials } \\
\text { (aluminum alloy Al6061, glass fiber } \\
\text { and carbon fiber reinforced plastic, } \\
\text { with aluminum foam core }\end{array}$ & $\begin{array}{l}\text { Sequential low-velocity off-panel } \\
\text { pre-impact and/or in-panel } \\
\text { post-compression tests } \\
\text { (Crashworthiness-experiment) }\end{array}$ & $\begin{array}{l}\text { The type of loading conditions affects different } \\
\text { material face sheets, but overall the } \\
\text { fiber-reinforced plastics performed better. }\end{array}$ & [41] \\
\hline $\begin{array}{l}\text { Sandwich panels made from } \\
\text { closed-cell aluminium foam cores } \\
\text { and aluminium face sheets }\end{array}$ & $\begin{array}{l}\text { Low velocity Impact } \\
\text { (perforation-simulation) }\end{array}$ & $\begin{array}{l}\text { For perforation application, it was found that the } \\
\text { sandwich panels performed poorly compared to } \\
\text { the monolithic aluminium panel. }\end{array}$ & [42] \\
\hline $\begin{array}{l}\text { Sandwich panel consists of aluminum } \\
\text { foam core with steel as face sheets }\end{array}$ & $\begin{array}{l}\text { Air-blast loading } \\
\text { (blast-simulation) }\end{array}$ & $\begin{array}{l}\text { Specific energy absorption increases with the } \\
\text { increase of foam thickness and the sandwich } \\
\text { panel can reduce peak acceleration by } 50 \% \\
\text { compared to steel plates. }\end{array}$ & [43] \\
\hline $\begin{array}{l}\text { Sandwich panel core is from } \\
\text { closed-cell aluminum foam. } \\
\text { The face sheets consists of three different } \\
\text { materials ( } 304 \text { stainless steel, } 5182 \text { aluminum } \\
\text { alloy and carbon fiber composite). }\end{array}$ & $\begin{array}{l}\text { Pendulum Blast test } \\
\text { (blast- experiment) }\end{array}$ & $\begin{array}{l}\text { The blast resistant of the sandwich panels } \\
\text { comprised of the composite face sheets } \\
\text { outperformed the metallic counterparts }\end{array}$ & {$[44]$} \\
\hline $\begin{array}{l}\text { Aluminum/foam/CFRP hybrid } \\
\text { sandwich tubes }\end{array}$ & $\begin{array}{c}\text { Compression test } \\
\text { (Crashworthiness-experiment } \\
\text { and simulation) }\end{array}$ & $\begin{array}{l}\text { Better crashworthiness characteristics to cost } \\
\text { of these hybrid structures were identified. }\end{array}$ & {$[45]$} \\
\hline $\begin{array}{l}\text { Steel plates as face sheets with } \\
\text { aluminum foam as core }\end{array}$ & $\begin{array}{c}\text { Compression test } \\
\text { (Crashworthiness-simulation) }\end{array}$ & $\begin{array}{l}\text { The usage of sandwich structure increased } \\
\text { the energy absorption capability for the } \\
\text { selected application. }\end{array}$ & [46] \\
\hline $\begin{array}{l}\text { Sandwich panels face sheets made } \\
\text { composite and aluminum whereas } \\
\text { the core was aluminum foam }\end{array}$ & $\begin{array}{l}\text { Low velocity impact test } \\
\text { (perforation- experiment) }\end{array}$ & $\begin{array}{l}\text { Sandwich panels with aluminium face sheets } \\
\text { showed higher SEA than composite face sheets. It } \\
\text { also performed better in other design constraints } \\
\text { such as cost, impact to environment, etc. }\end{array}$ & [47] \\
\hline $\begin{array}{l}\text { Sandwich panel core is from } \\
\text { closed-cell aluminum foam. } \\
\text { The face sheets consists of three different } \\
\text { materials ( } 304 \text { stainless steel, } 5182 \text { aluminum } \\
\text { alloy and carbon fiber composite). }\end{array}$ & $\begin{array}{l}\text { Ballistic Pendulum } \\
\text { (Blast-experiment and simulation) }\end{array}$ & $\begin{array}{l}\text { The sandwich structure with descending gradient } \\
\text { density of the foam core provided the highest } \\
\text { blast resistance. Even and uneven face sheet } \\
\text { thickness influence the blast resistant performance, } \\
\text { depending on the intensity of the blast }\end{array}$ & [48] \\
\hline
\end{tabular}


Table 2. Cont.

\begin{tabular}{ccc}
\hline Sandwich Construction & Loading/Application & Summary of Findings \\
$\begin{array}{c}\text { Double wall tubular structure filled } \\
\text { with metallic aluminum foam. }\end{array}$ & $\begin{array}{c}\text { Compression test } \\
\text { (Crashworthiness-experiment } \\
\text { and simulation) }\end{array}$ & $\begin{array}{c}\text { (1) strain rate of the foam core is important in } \\
\text { defining the crushing behavior which is linked to } \\
\text { the energy absorption capabilities. (2) Interaction } \\
\text { between the foam and the tube wall enhance } \\
\text { multiple propagating folds, which enhance } \\
\text { crashworthiness performance }\end{array}$ \\
$\begin{array}{c}\text { Functionally graded } \\
\text { close-celled aluminum foam cores } \\
\text { with stainless steel face sheets }\end{array}$ & $\begin{array}{c}\text { Sir blast loading } \\
\text { [Blast-simulation) }\end{array}$ & $\begin{array}{c}\text { Sandwich panels with graded foam core } \\
\text { possess smaller central transverse deflection } \\
\text { and superior blast resistance. }\end{array}$ \\
\hline
\end{tabular}

\subsection{Architected Core Structure}

Foams, especially the metal foams, have some challenges. One of the common challenges is the non-uniformity of the cell structure for the foam due to the existing fabrication process (foaming of melts/powder). This results in a lack of efficiency in batch or mass production, especially when producing near-net products or tailoring for customized applications. This is true when one wants to fabricate functionally graded metal foams, for example. Due to enhancements in manufacturing technology such as 3D printing, new cores can be design and developed to fulfill certain functional requirements (architected core). This review will cover such cores as: (a) honeycomb cores; (b) truss/lattice structure cores; (c) origami/fold-cores; (d) auxetic core, and (f) tubular cores.

\subsubsection{Honeycomb Structure}

Honeycomb sandwich structures (Figure 3) are one of the earliest architected core sandwich structures used for dynamic loading events. Table 3 details a summary of some of the related applications of such sandwich structures. The typical applications reported in the literature are for low velocity impact (perforation), shock wave, and crashworthiness applications. For sandwich structure face sheets, typical materials used are either metals (stainless steel/aluminum) or fiber composites. For the core, the most common honeycomb material used was aluminum followed by polymeric and paper (Nomex). Some of the key findings are as follows:

- Graded honeycomb cores are better than uniform density cores.

- Honeycomb geometry plays a vital role in the energy absorption capability.

- Failure mechanisms of the face sheets and core play a vital role in the energy absorption capability.

- Parametric design is crucial to optimize the sandwich structure for energy absorption.

- For perforation applications, it was found that most of the energy absorption is due to the face sheet of the panels.

- Sandwich structures used for crashworthiness related applications/testing conditions demonstrated progressive crushing, especially with honeycomb that is filled with foam.

- Strain rate of the honeycomb is important in defining the crushing behavior, which is linked to the energy absorption capabilities.

\section{face sheet}

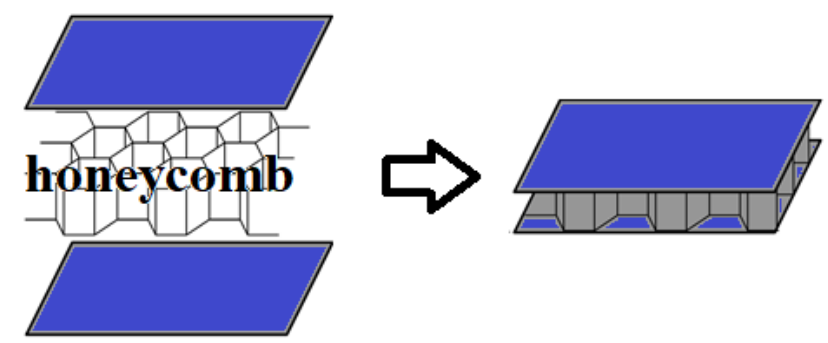

Figure 3. Honeycomb sandwich panel. 
Table 3. Sandwich structure with honeycomb core.

\begin{tabular}{|c|c|c|c|}
\hline Sandwich Construction & Loading/Application & Summary of Findings & Reference \\
\hline $\begin{array}{l}\text { Aluminium face sheets with triple } \\
\text { layered graded honeycomb cores }\end{array}$ & $\begin{array}{l}\text { Blast loading } \\
\text { (blast-experimental } \\
\text { and finite element) }\end{array}$ & $\begin{array}{l}\text { Effects of geometric configuration on type of } \\
\text { deformation modes and blast resistance were } \\
\text { studied. Core arrangement affected the energy } \\
\text { absorption and blast resistance capabilities. } \\
\text { Core with higher density arranged closer } \\
\text { proximally performed better. }\end{array}$ & [51] \\
\hline $\begin{array}{l}\text { Steel face sheet with } \\
\text { aluminium honeycomb core }\end{array}$ & $\begin{array}{l}\text { Blast loading_uniform } \\
\text { and localized } \\
\text { (Blast-experiment) }\end{array}$ & $\begin{array}{l}\text { Failure performance or blast resistant was better for } \\
\text { uniform loading than under localized loading. It } \\
\text { was also found that the load transfer to the back face } \\
\text { sheet depends on the load intensity, core thickness } \\
\text { and flexibility of the sandwich structure. }\end{array}$ & {$[52,53]$} \\
\hline $\begin{array}{l}\text { Sandwich panel steel face sheets with } \\
\text { unbounded aluminium foam or } \\
\text { hexagonal honeycomb cores }\end{array}$ & $\begin{array}{l}\text { Air Blast loading } \\
\text { (Blast-experimental) }\end{array}$ & $\begin{array}{l}\text { Face sheet thickness has a significant effect on the } \\
\text { blast resistance performance for both the foam and } \\
\text { honeycomb cores. The honeycomb core performed } \\
\text { better than the metallic foam core. }\end{array}$ & [54] \\
\hline $\begin{array}{l}\text { Sandwich panels with carbon/epoxy skins } \\
\text { and an aluminium honeycomb core }\end{array}$ & $\begin{array}{c}\text { Impact Loading } \\
\text { (perforation-simulation) }\end{array}$ & $\begin{array}{l}\text { Most of the impact energy was absorbed } \\
\text { by the skins (between } 80-90 \% \text { ) }\end{array}$ & [55] \\
\hline $\begin{array}{l}\text { Sandwich panels made from aluminum } \\
\text { face sheets and honeycomb cores. Some } \\
\text { cores reinforced with aluminium tubes. }\end{array}$ & $\begin{array}{c}\text { Compression Impact } \\
\text { testing-drop weight } \\
\text { (crashworthiness-experiment) }\end{array}$ & $\begin{array}{l}\text { The tube structure in some of the honeycomb cores } \\
\text { exhibited higher and uniform energy absorption. } \\
\text { Such structures had better impact resistance as well. }\end{array}$ & [56] \\
\hline $\begin{array}{l}\text { Sandwich panels consist of carbon } \\
\text { and glass fiber face sheets and } \\
\text { Nomex honeycomb core }\end{array}$ & $\begin{array}{l}\text { Impact testing } \\
\text { (perforation-experimental } \\
\text { and simulation) }\end{array}$ & $\begin{array}{l}\text { The honeycomb geometry (cell design) and core } \\
\text { thickness effects the peak force and energy } \\
\text { absorption capabilities of the sandwich panels. }\end{array}$ & [57] \\
\hline $\begin{array}{l}\text { Sandwich panels for both honeycomb core } \\
\text { and face sheets made up from aluminium }\end{array}$ & $\begin{array}{l}\text { Pendulum impact system } \\
\text { (perforation-experimental } \\
\text { and simulation) }\end{array}$ & $\begin{array}{l}\text { Most of the impact energy was absorbed through } \\
\text { plastic deformation by the face sheets and the core } \\
\text { through plastic deformation. Different impact } \\
\text { energies demonstrated different failure mechanisms. }\end{array}$ & [58] \\
\hline $\begin{array}{c}\text { Fiber metal laminates were used as skin on } \\
\text { polypropylene honeycomb core to form a } \\
\text { sandwich structure }\end{array}$ & $\begin{array}{l}\text { Impact testing } \\
\text { (perforation- experiment) }\end{array}$ & $\begin{array}{l}\text { At low impact energies, there were only } \\
\text { indentations on the front face sheet. Beyond the } \\
\text { impact threshold energy, there was delamination } \\
\text { of the skins and global bending of the structure. }\end{array}$ & [59] \\
\hline $\begin{array}{l}\text { Face sheets and honeycomb core for the } \\
\text { sandwich panels made up from aluminum }\end{array}$ & $\begin{array}{l}\text { Impact testing } \\
\text { (perforation-experiment } \\
\text { and simulation) }\end{array}$ & $\begin{array}{l}\text { When the face sheet thickness were increased, it was } \\
\text { found that the peak forces, SEA and EA also increases. } \\
\text { Increasing the honeycomb cell size increases the } \\
\text { SEA. The findings indicate that such sandwich } \\
\text { panels can be optimized in terms of its design } \\
\text { parameters to achieve excellent impact resistance. }\end{array}$ & {$[60]$} \\
\hline $\begin{array}{l}\text { Face sheets and honeycomb core for the } \\
\text { sandwich panels made up from aluminum }\end{array}$ & $\begin{array}{l}\text { Impact testing } \\
\text { (perforation-experiment } \\
\text { and simulation) }\end{array}$ & $\begin{array}{l}\text { The structural integrity and stability was increased } \\
\text { by reducing the cell size of the honeycomb. The } \\
\text { height of the core does not affect the impact } \\
\text { response or energy absorption. }\end{array}$ & [61] \\
\hline $\begin{array}{l}\text { Face sheets and honeycomb core for the } \\
\text { sandwich panels made up from aluminum }\end{array}$ & $\begin{array}{l}\text { High velocity Impact testing } \\
\text { (perforation-experiment } \\
\text { and simulation) }\end{array}$ & $\begin{array}{l}\text { By increasing face sheet thickness and reducing } \\
\text { honeycomb cell size, enhancement of perforation } \\
\text { resistance of sandwich panels was achieved. The } \\
\text { face sheets contributed most to energy absorption. } \\
\text { Optimization of the face sheets and honeycomb } \\
\text { design parameters are required to achieved the } \\
\text { desired impact resistant. }\end{array}$ & [62] \\
\hline $\begin{array}{l}\text { Aluminum honeycomb sandwich } \\
\text { structures with carbon fiber } \\
\text { composite face sheets }\end{array}$ & $\begin{array}{l}\text { Impact testing } \\
\text { (perforation-experiment } \\
\text { and simulation) }\end{array}$ & $\begin{array}{l}\text { Impact response and damage behavior are affected } \\
\text { by structural parameters. Face sheet thickness affects } \\
\text { the impact resistance performance whereas honeycomb } \\
\text { cell design has influence on the impact load. }\end{array}$ & [63] \\
\hline $\begin{array}{c}\text { The sandwich face sheet is from aluminum } \\
\text { whereas the core is hybrid (corrugated thin } \\
\text { aluminum plate and trapezoidal } \\
\text { aluminium honeycomb }\end{array}$ & $\begin{array}{l}\text { Compression Test } \\
\text { (Crashworthiness-experiment } \\
\text { and simulation) }\end{array}$ & $\begin{array}{l}\text { The proposed system of honeycomb-corrugation } \\
\text { hybrid structures are promising candidate energy } \\
\text { absorbing applications. This is due to the complex } \\
\text { deformation mechanism, which prevented } \\
\text { honeycomb cell wall buckling. }\end{array}$ & [64] \\
\hline $\begin{array}{l}\text { The sandwich hybrid core is total } \\
\text { aluminium consist of honeycomb and a } \\
\text { grid of flat plates. The face sheets are } \\
\text { from carbon fiber composites }\end{array}$ & $\begin{array}{l}\text { Compression Test } \\
\text { (Crashworthiness-experiment } \\
\text { and simulation) }\end{array}$ & $\begin{array}{c}\text { The combination of honeycomb and flat plats } \\
\text { prevented both interfacial debonding and } \\
\text { local buckling of core. This resulted in } \\
\text { higher energy absorption. }\end{array}$ & {$[65]$} \\
\hline $\begin{array}{l}\text { Sandwich face sheets and honeycomb } \\
\text { core made from aluminium filled with } \\
\text { polyurethane foam }\end{array}$ & $\begin{array}{c}\text { Impact testing } \\
\text { (perforation-simulation) }\end{array}$ & $\begin{array}{c}\text { The study found that the filling of honeycomb } \\
\text { structure with high-density foam material } \\
\text { had better energy absorption and impact } \\
\text { resistance capabilities. }\end{array}$ & {$[66]$} \\
\hline $\begin{array}{l}\text { Sandwich panel made from aluminum } \\
\text { (face sheets and core). The core was } \\
\text { designed to be wavy. }\end{array}$ & $\begin{array}{c}\text { Compression Test } \\
\text { (Crashworthiness-simulation) }\end{array}$ & $\begin{array}{l}\text { The sandwich panel had superior energy absorption } \\
\text { capability compared with the conventional } \\
\text { honeycomb sandwich panel, with a larger wave } \\
\text { number and amplitude shows higher SEA. }\end{array}$ & [67] \\
\hline
\end{tabular}




\subsubsection{Truss/Lattice Like Structures as Core}

Sandwich structures with a truss/lattice structure (Figure 4) were adopted as the core is a new type of architected core sandwich structure used for dynamic loading events. Table 4 details a summary of some of the related applications of such sandwich structures. The typical applications reported in the literature are for low velocity impact (perforation), shock wave, and crashworthiness applications. For sandwich structure face sheets, typical materials used are either metals (stainless steel/aluminum) or fiber composites. For the core structure, the most common material used was metal followed by polymer. Some of the key findings are as follows:

- Higher aerial density of the truss like structure enhances the energy absorption capabilities.

- The truss/lattice core with foam filling enhances the energy absorption and impact resistance capabilities.

- The empty lattice core does not support perforation related applications.

- The type of lattice/truss structure geometry design affects the energy absorption capabilities.

- Failure mechanisms of the face sheets and core play a vital role in the energy absorption capability.
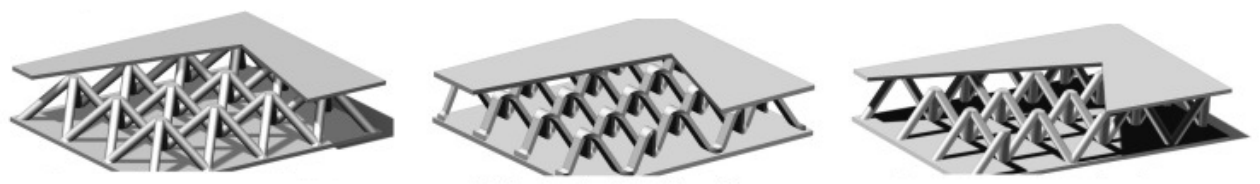

Figure 4. Lattice core sandwich panel. (image source: “Creative Commons Multifunctional sandwich panel with metallic lattice cores" by Zhang et al. https:/ / doi.org/10.3390/en10070906 (accessed on 18 August 2021), used under CC BY 4.0, modified from original).

Table 4. Sandwich structure with truss/lattice like structure as core.

\begin{tabular}{|c|c|c|c|}
\hline Sandwich Construction & Loading/Application & Summary of Findings & Reference \\
\hline $\begin{array}{l}\text { Aluminium pyramidal lattice core } \\
\text { sandwich panel with polyurethane foam. } \\
\text { Face sheets from carbon fiber composites }\end{array}$ & $\begin{array}{l}\text { Impact testing } \\
\text { (perforation-experiment } \\
\text { and simulation) }\end{array}$ & $\begin{array}{l}\text { The higher density of the pyramidal } \\
\text { lattice structure exhibited better } \\
\text { energy absorption capabilities }\end{array}$ & {$[68]$} \\
\hline $\begin{array}{l}\text { Aluminum sandwich panel composed } \\
\text { of identical face sheets and tetrahedral } \\
\text { lattice cores. }\end{array}$ & $\begin{array}{l}\text { Air blast testing-ballistic } \\
\text { pendulum system } \\
\text { (Blast-experiment) }\end{array}$ & $\begin{array}{l}\text { Tetrahedral lattice sandwich panels have better } \\
\text { impulsive resistance than honeycomb structure } \\
\text { made from the same material. }\end{array}$ & [69] \\
\hline $\begin{array}{l}\text { Sandwich panel consists of tetrahedral } \\
\text { truss core and face sheet made of } \\
\text { carbon/epoxy prepregs. Some of the } \\
\text { samples were filled with polymer foam }\end{array}$ & $\begin{array}{l}\text { Impact testing-gas gun } \\
\text { (perforation-experiment) }\end{array}$ & $\begin{array}{l}\text { The foam filled lattice structure had better impact } \\
\text { resistance compared to the truss core structure only. }\end{array}$ & {$[70]$} \\
\hline $\begin{array}{l}\text { Sandwich panel consists of pyramidal } \\
\text { lattice truss core and face sheet made of } \\
\text { stainless steel. The voids are filled with } \\
\text { ceramics and polymers }\end{array}$ & $\begin{array}{c}\text { Impact testing } \\
\text { (perforation-experiment) }\end{array}$ & $\begin{array}{l}\text { Empty lattice structure does not contribute } \\
\text { perforation. The filling of the voids with ceramic } \\
\text { and polymers improves the impact resistance. }\end{array}$ & {$[71]$} \\
\hline $\begin{array}{c}\text { Sandwich structures with Y-shaped cores } \\
\text { were fabricated using unidirectional } \\
\text { carbon/epoxy prepreg }\end{array}$ & $\begin{array}{c}\text { Compression Test } \\
\text { (Blast/Crashworthiness - experimental } \\
\text { and simulation) }\end{array}$ & $\begin{array}{l}\text { Sandwich structures which had higher relative } \\
\text { densities (more plies of fiber composites) had } \\
\text { better energy absorption. However, no progressive } \\
\text { collapse was observed. }\end{array}$ & {$[72]$} \\
\hline $\begin{array}{l}\text { Sandwich panel consists of aluminum } \\
\text { pyramidal lattice truss core and face sheet } \\
\text { made of carbon fiber composite }\end{array}$ & $\begin{array}{l}\text { Compression test and low } \\
\text { velocity impact(perforation/ } \\
\text { crashworthiness-experiment } \\
\text { and simulation) }\end{array}$ & $\begin{array}{l}\text { Under compression testing and impact test, the } \\
\text { core structure failed in buckling. The higher the } \\
\text { density of the core, the better the energy absorption. }\end{array}$ & [73] \\
\hline $\begin{array}{l}\text { Sandwich panel consists of hourglass and } \\
\text { pyramidal lattice truss core and face sheet } \\
\text { made of stainless steel }\end{array}$ & $\begin{array}{l}\text { Underwater blast test } \\
\text { (Blast-experiment) }\end{array}$ & $\begin{array}{l}\text { The impact performance of the hourglass lattice } \\
\text { panels was better than the pyramidal lattice panels. }\end{array}$ & [74] \\
\hline $\begin{array}{l}\text { Sandwich panel consists of pyramidal } \\
\text { lattice truss core and face sheet made of } \\
\text { stainless steel }\end{array}$ & $\begin{array}{c}\text { Blast loading } \\
\text { (Blast/perforation-experiment } \\
\text { and simulation) }\end{array}$ & $\begin{array}{l}\text { The impact resistance performance of the } \\
\text { sandwich structure was found to be very } \\
\text { similar to monolithic plates. }\end{array}$ & [75] \\
\hline $\begin{array}{l}\text { Lattice core sandwich cylinder made from } \\
\text { aluminum both the core and inner/outer } \\
\text { shell of cylinder }\end{array}$ & $\begin{array}{l}\text { Internal Blast Loading } \\
\text { (Blast-simulation) }\end{array}$ & $\begin{array}{l}\text { The core geometry and core arrangement have } \\
\text { significant effects on the blast resistance. The ticker } \\
\text { the core wall, the less energy is absorbed. } \\
\text { Asymmetrical design of the cylinder shells (inner } \\
\text { and outer) enhances the blast resistance. }\end{array}$ & {$[76]$} \\
\hline
\end{tabular}


Table 4. Cont.

\begin{tabular}{|c|c|c|c|}
\hline Sandwich Construction & Loading/Application & Summary of Findings & Reference \\
\hline $\begin{array}{l}\text { Sandwich panel consists of stainless steel } \\
\text { pyramidal lattice structure as core and } \\
\text { face sheet made of stainless steel }\end{array}$ & $\begin{array}{l}\text { Underwater blast loading } \\
\text { (Blast-experiment/simulation) }\end{array}$ & $\begin{array}{l}\text { The front face sheet thickness influences the lattice } \\
\text { structures' deflection and energy absorption } \\
\text { capabilities. An optimal value is desired for } \\
\text { improving the impact resistance of the } \\
\text { sandwich structure }\end{array}$ & [77] \\
\hline $\begin{array}{l}\text { Sandwich panels with lattice truss core } \\
\text { filled by shear thickening fluid }\end{array}$ & $\begin{array}{c}\text { Compressive Test } \\
\text { (Blast-theoretical/simulation) }\end{array}$ & $\begin{array}{l}\text { Energy absorption of panels increases } \\
\text { with the increase of the fluid viscosity. }\end{array}$ & [78] \\
\hline $\begin{array}{l}\text { Sandwich panels made from Nylon with } \\
\text { re-entrant Auxetic structure, the } \\
\text { octet-truss structure and the BCC lattice } \\
\text { structure for the core design. }\end{array}$ & $\begin{array}{l}\text { Drop weight Compressive Test } \\
\text { (Crashworthiness-experiment) }\end{array}$ & $\begin{array}{l}\text { The geometrical design of the core structures } \\
\text { significantly influences the impact energy } \\
\text { absorption capabilities. The auxetic structure } \\
\text { had better overall performance. }\end{array}$ & [79] \\
\hline
\end{tabular}

\subsubsection{Origami/Foldcore Structures}

Sandwich structures with origami type structure were adopted as the core is a new type of architected core sandwich structure used for dynamic loading events. Figure 5 depicts some example of origami patterns that can be used to construct the core of a sandwich panel or beam. Table 5 details a summary of some of the related applications of such sandwich structures. The typical applications reported in the literature are for low velocity impact (perforation), shock wave, and crashworthiness applications. For sandwich structure face sheets, typical materials used are either metals (stainless steel/aluminum) or fiber composites. For the core structure, the most used material was metal followed by polymer. Some of the key findings are as follows:

- $\quad$ Perforation energy is highly related to the origami wall thickness.

- The origami structure provides multiple hinges for plastic deformation, which enhances energy absorption capabilities.

- Geometrical parameters of the origami are crucial to the development and optimal design for energy absorption.

- The origami sandwich structure was found to be better than the honeycomb sandwich structure.

- The origami structure can be optimized and tailored easily for various dynamic related events.
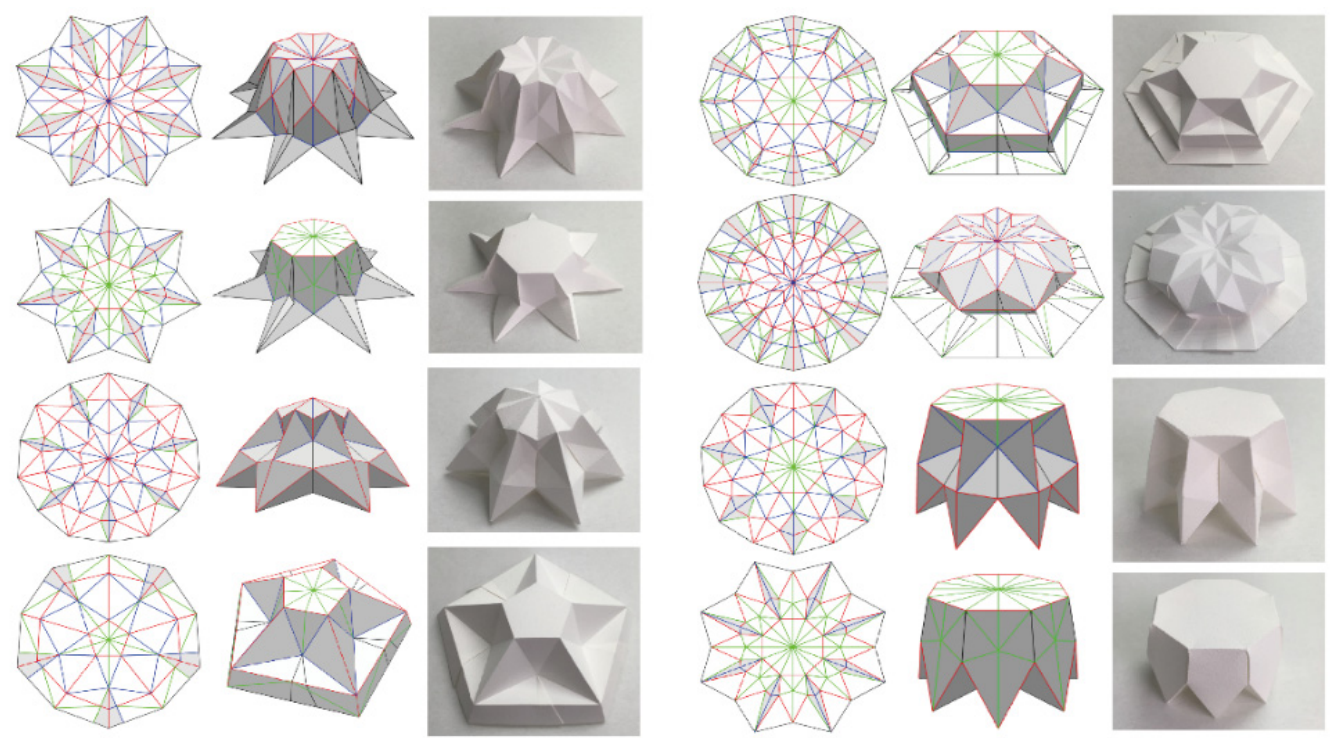

Figure 5. Example of origami patterns that can be used to construct the core of a sandwich panel. (image source: "Creative Commons Multifunctional resulting origami pieces with 3D flaps" by Zhao et al. https:/ / doi.org/10.3390/sym10100469 (accessed on 18 August 2021), used under CC BY 4.0). 
Table 5. Sandwich structure with origami/foldcore.

\begin{tabular}{|c|c|c|c|}
\hline Sandwich Construction & Loading/Application & Summary of Findings & Reference \\
\hline $\begin{array}{l}\text { Sandwich panels consists of aluminum } \\
\text { origami core and aluminum face sheets }\end{array}$ & $\begin{array}{c}\text { Impact testing gas gun } \\
\text { (Perforation-experiment/simulations) }\end{array}$ & $\begin{array}{l}\text { Deformation is localized without global } \\
\text { deflection. Energy absorption was related to } \\
\text { plastic deformation which dependent on the } \\
\text { shape of the projectile. Perforation energy is } \\
\text { linearly related to the origami wall thickness. }\end{array}$ & [80] \\
\hline $\begin{array}{l}\text { Aluminum Ron Resch origami core } \\
\text { sandwich structure }\end{array}$ & $\begin{array}{c}\text { Compression test } \\
\text { (Crashworthiness-experiment/simulation) }\end{array}$ & $\begin{array}{l}\text { The origami structure showed reduction in peak } \\
\text { load due to formation of multiple plastic hinge } \\
\text { lines. Overall, the performance of the origami } \\
\text { panel is similar to the honeycomb structure }\end{array}$ & [81] \\
\hline $\begin{array}{l}\text { Sandwich panels of PET and PEEK } \\
\text { foldcores with aluminum face sheets }\end{array}$ & $\begin{array}{c}\text { Compression test } \\
\text { (Crashworthiness - experiment/simulation) }\end{array}$ & $\begin{array}{l}\text { It was found that the PEEK foldcores have better } \\
\text { energy absorption capabilities. The geometrical } \\
\text { parameters are crucial in developing and } \\
\text { optimal design for energy absorption. }\end{array}$ & [82] \\
\hline $\begin{array}{l}\text { High Strength Low Alloy steel was used } \\
\text { for the sandwich panel consisting of } \\
\text { origami core and face sheets }\end{array}$ & $\begin{array}{l}\text { Impulsive load test } \\
\text { (Blast-simulation) }\end{array}$ & $\begin{array}{l}\text { The panels consisting or the origami core are } \\
\text { potential candidates for blast mitigation } \\
\text { applications. The core pattern and geometry } \\
\text { parameter influences the dynamic } \\
\text { response of the panel. }\end{array}$ & [83] \\
\hline $\begin{array}{l}\text { High Strength Low Alloy steel was used } \\
\text { for the sandwich panel consisting of } \\
\text { origami core and face sheets }\end{array}$ & $\begin{array}{l}\text { Compression and blast test } \\
\text { (Blast/Crashworthiness—-simulation) }\end{array}$ & $\begin{array}{l}\text { For low to moderate load intensities, origami } \\
\text { core absorbed more plastic energy than } \\
\text { corresponding honeycomb core. The origami } \\
\text { pattern and geometry parameters can be tailored } \\
\text { to meet structural response requirements. }\end{array}$ & {$[84]$} \\
\hline $\begin{array}{l}\text { Sandwich panels consist of carbon } \\
\text { fiber face sheets and foldcores made up } \\
\text { from aramid paper }\end{array}$ & $\begin{array}{c}\text { Impact test } \\
\text { (Blast_-experiment/simulation) }\end{array}$ & $\begin{array}{l}\text { The foldcores core degradation and } \\
\text { friction affects the sandwich's energy } \\
\text { absorption capabilities. }\end{array}$ & [85] \\
\hline $\begin{array}{c}\text { The sandwich core has a origami inspired } \\
\text { honeycomb structure made from resins. } \\
\text { Whereas the face sheets are made from } \\
\text { aluminium alloy. }\end{array}$ & $\begin{array}{c}\text { Drop-weight impact } \\
\text { (Perforation-simulation) }\end{array}$ & $\begin{array}{l}\text { The origami sandwich panel has better } \\
\text { energy absorption characteristics than } \\
\text { traditional honeycomb structure }\end{array}$ & [86] \\
\hline $\begin{array}{l}\text { Sandwich structure with foldcore/origami } \\
\text { fabricated from brass H62. }\end{array}$ & $\begin{array}{c}\text { Compression test } \\
\text { (Crashworthiness-experiment/simulation) }\end{array}$ & $\begin{array}{l}\text { The new kirigami inspired foldcore had better } \\
\text { energy absorption characteristics than traditional } \\
\text { honeycomb structure and Miura-ori core structure. }\end{array}$ & [87] \\
\hline $\begin{array}{l}\text { Sandwich beam with Miura-origami core } \\
\text { and and face sheets made from steel }\end{array}$ & $\begin{array}{c}\text { Blast loading } \\
\text { (Blast-experiment) }\end{array}$ & $\begin{array}{c}\text { The origami pattern (unit cell) has a wide range } \\
\text { of parameters, which gives unique mechanical } \\
\text { properties. This in returns affects the level of } \\
\text { energy absorption. }\end{array}$ & {$[88]$} \\
\hline
\end{tabular}

\subsubsection{Auxetic/Meta-Structured Core Structures}

Auxetic core structures (Figure 6) are structures with a negative Poisson's ratio. As a new class of material/structure, it has been studied recently. Such auxetic structures, when pulled, become thicker in the direction perpendicular to the force. Further, 3D printing can be used here to fabricate such structures easily where the face sheet is printed on the core, overcoming the limitation of delamination/debonding of the face sheet from the core. Sandwich structures with such a core structure represent a new type of architected core sandwich structure used for dynamic loading events. Table 6 details a summary of some of the related applications of such sandwich structures. The typical applications reported in the literature are for low velocity impact (perforation), shock wave, and crashworthiness applications. For sandwich structure face sheets, typical materials used are either metals (stainless steel/aluminum) or fiber composites. For the core structure, the most common material used was metal followed by polymer. Some of the key findings are as follows:

- The core design geometrical parameters have significant effects on the failure mechanism and energy absorption of the auxetic structures.

- The geometry parameters, such as thicknesses and core density, affect the ballistic resistance performance.

- It was also found that auxetic honeycomb, as a core in sandwich panels, provides good ballistic protection.

- The auxetic sandwich panel has good energy absorption capabilities. 


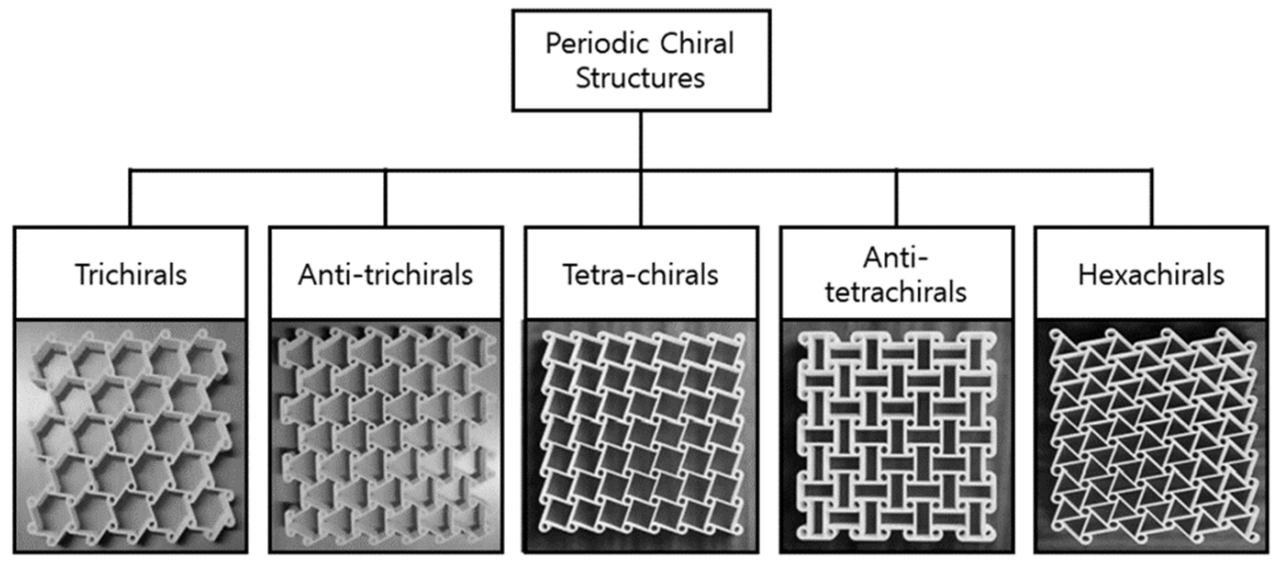

Figure 6. Example of auxetic structure that can be used to construct the core of a sandwich panel. (image source: "Creative Commons Multifunctional classification and representative structures of periodic chiral structures" by Kelkar et al. https: / doi.org/10.3390/s20113132 (accessed on 18 August 2021), used under CC BY 4.0).

Table 6. Sandwich structure with auxetic core

\begin{tabular}{|c|c|c|c|}
\hline Sandwich Construction & Loading/Application & Summary of Findings & Reference \\
\hline $\begin{array}{l}\text { Sandwich panel with auxetic core structure, } \\
\text { fabricated from PLA polymers (3D printed) }\end{array}$ & $\begin{array}{c}\text { Impact Test } \\
\text { (perforation-experiment/simulation) }\end{array}$ & $\begin{array}{l}\text { The auxetic sandwich panel has good energy } \\
\text { absorption capabilities }\end{array}$ & [89] \\
\hline $\begin{array}{c}\text { Sandwich panel with auxetic core structure, } \\
\text { fabricated from aluminum }\end{array}$ & $\begin{array}{c}\text { Impact Test } \\
\text { (perforation-simulation) }\end{array}$ & $\begin{array}{l}\text { The geometry parameters such as thicknesses } \\
\text { and core density, affects the ballistic resistance } \\
\text { performance. It was also found that } \\
\text { auxetic honeycomb core as sandwich are } \\
\text { good for ballistic protection. }\end{array}$ & {$[90]$} \\
\hline $\begin{array}{c}\text { Sandwich panel with auxetic core structure, } \\
\text { fabricated from aluminum and face sheets } \\
\text { from steel }\end{array}$ & $\begin{array}{l}\text { Blast Loading } \\
\text { (Blast-simulation) }\end{array}$ & $\begin{array}{l}\text { When compared to monolithic plates, the } \\
\text { auxetic sandwich panels absorb double the } \\
\text { amount of impulsive energy via plastic } \\
\text { deformation and significantly reduces the back } \\
\text { facet's maximum velocity. }\end{array}$ & [91-93] \\
\hline $\begin{array}{l}\text { 3D printed polymeric PLA meta-sandwich } \\
\text { structures made of cubic, octet and Isomax } \\
\text { cellular cores }\end{array}$ & $\begin{array}{c}\text { Impact test } \\
\text { (perforation-experiment/simulation) }\end{array}$ & $\begin{array}{l}\text { The core design geometrical parameters have } \\
\text { significant effects on failure mechanism and } \\
\text { energy absorption of the auxetic structures. } \\
\text { Isomax cellular cores had the highest energy } \\
\text { absorption capabilities. }\end{array}$ & [94] \\
\hline $\begin{array}{l}\text { Sandwich panels made from Nylon with } \\
\text { re-entrant Auxetic structure, the octet-truss } \\
\text { structure and the BCC lattice structure for } \\
\text { the core design. }\end{array}$ & $\begin{array}{l}\text { Drop weight Compressive Test } \\
\text { (Crashworthiness-experiment) }\end{array}$ & $\begin{array}{l}\text { The geometrical design of the core structures } \\
\text { significantly influences the impact energy } \\
\text { absorption capabilities. The auxetic structure } \\
\text { had better overall performance. }\end{array}$ & [79] \\
\hline $\begin{array}{l}\text { Face sheets from braided fiber composites } \\
\text { and sandwich aluminum core from auxetic } \\
\text { 3D re-entrant lattices }\end{array}$ & $\begin{array}{c}\text { Impact test } \\
\text { (perforation-experiment/simulation) }\end{array}$ & $\begin{array}{l}\text { Auxetic lattice core sandwich structure } \\
\text { showed significant improvement in } \\
\text { dissipating energy. The proposed sandwich } \\
\text { design can be used for bulletproof body } \\
\text { armors and safety vehicle parts. }\end{array}$ & [95] \\
\hline $\begin{array}{l}\text { Sandwich structure with auxetic, truss and } \\
\text { hexagonal cores fabricated from polymer } \\
\text { digital material and face sheets from carbon } \\
\text { fiber composite. }\end{array}$ & $\begin{array}{l}\text { Impact test } \\
\text { (perforation-experiment) }\end{array}$ & $\begin{array}{l}\text { The auxetic panel had lower impact resistance } \\
\text { compared to the truss and hexagonal core } \\
\text { panels. However, the auxetic panels had } \\
\text { robustness and durability, because this panel } \\
\text { was able to absorb multi hits }\end{array}$ & [96] \\
\hline $\begin{array}{c}\text { Sandwich panels made up from aluminum } \\
\text { (face sheets and core). The core consists } \\
\text { of a honeycomb with the re-entrant } \\
\text { hexagonal cells. }\end{array}$ & $\begin{array}{c}\text { Impact test } \\
\text { (perforation-experiment/simulation) }\end{array}$ & $\begin{array}{c}\text { The auxetic panels perform better than } \\
\text { conventional honeycomb panels of the same } \\
\text { size, areal density and material (in terms of } \\
\text { blast resistance) }\end{array}$ & [97] \\
\hline $\begin{array}{l}\text { Sandwich panels with aluminium } \\
\text { re-entrant hexagon honeycomb as } \\
\text { core and steel face sheet }\end{array}$ & $\begin{array}{c}\text { Impact blast } \\
\text { (Blast_experiment/simulation) }\end{array}$ & $\begin{array}{l}\text { The blast resistance performance indicators } \\
\text { were more sensitive to thickness parameters. }\end{array}$ & [98] \\
\hline $\begin{array}{l}\text { Sandwich panels with auxetic chiral cellular } \\
\text { structure core and face sheets were 3D } \\
\text { printed from titanium alloy }\end{array}$ & $\begin{array}{c}\text { Blast loading } \\
\text { (Blast_-experiment/simulation) }\end{array}$ & $\begin{array}{l}\text { When thicker face sheet is used, the overall } \\
\text { deformation was reduced, however highest } \\
\text { SEA was achieved with thinner face plates. } \\
\text { Chiral unit cell amplitudes affects the energy } \\
\text { absorbing capabilities. }\end{array}$ & [99] \\
\hline
\end{tabular}


Table 6. Cont.

\begin{tabular}{|c|c|c|c|}
\hline Sandwich Construction & Loading/Application & Summary of Findings & Reference \\
\hline $\begin{array}{c}\text { The entire sandwich panel (face sheets } \\
\text { and auxetic core) was made from } \\
\text { aluminum alloy }\end{array}$ & $\begin{array}{c}\text { Blast loading } \\
\text { (Blast_-experiment/simulation) }\end{array}$ & $\begin{array}{l}\text { The auxetic graded honeycomb cores with } \\
\text { higher density on the upper layer had better } \\
\text { blast resistance performance. }\end{array}$ & [100] \\
\hline $\begin{array}{l}\text { Sandwich panels with double arrowhead } \\
\text { honeycomb. The core and the face sheets } \\
\text { made from stainless steel. }\end{array}$ & $\begin{array}{c}\text { Blast loading } \\
\text { (Blast-experiment/simulation) }\end{array}$ & $\begin{array}{l}\text { The blast resistance of this panel was } \\
\text { enhanced by filling with polyurethane foam. }\end{array}$ & [101] \\
\hline $\begin{array}{l}\text { Sandwich panels fabricatedwith carbon/fiber } \\
\text { epoxy composite face sheets, polyurethane } \\
\text { rigid foam core or 3D printed PLAplastic } \\
\text { cellular honeycombs head (hexagonal, } \\
\text { re-entrant, hexachiral and arrowhead). }\end{array}$ & $\begin{array}{c}\text { Impact test } \\
\text { (perforation-experiment/simulation) }\end{array}$ & $\begin{array}{l}\text { The arrowhead and hexachiral configurations } \\
\text { are good for blast resistance applications } \\
\text { involving impacts under large deformations. }\end{array}$ & [102] \\
\hline $\begin{array}{l}\text { The sandwich panel, including core } \\
\text { (double-V auxetic structure cor) and face } \\
\text { sheets, fabricated from a high-ductility } \\
\text { stainless steel alloy. }\end{array}$ & $\begin{array}{c}\text { Air blast loading } \\
\text { (Blast-experiment/simulation) }\end{array}$ & $\begin{array}{l}\text { The sandwich panel with auxetic core } \\
\text { performed much better both in lightweight } \\
\text { and protection than solid plate }\end{array}$ & [103] \\
\hline
\end{tabular}

\subsubsection{Tubular Core-Like Structures}

For this type of sandwich structure, the core structure is comprised of tubes (Figure 7). Table 7 details a summary of some of the related applications of such sandwich structures. The typical applications reported in the literature are for low velocity impact (perforation), shock wave, and crashworthiness applications. For sandwich structure face sheets, typical materials used are either metals (stainless steel/aluminum) or fiber composites. For the core structure, the most common material used was metal followed by polymer. Some of the key findings are as follows:

- Such a core design provides good blast resistance and crashworthiness, although less perforation related.

- The tube arrangement between the face sheets is crucial because it affects the plastic hinge formation.

- Tubes filled with foams have good energy absorption capabilities.
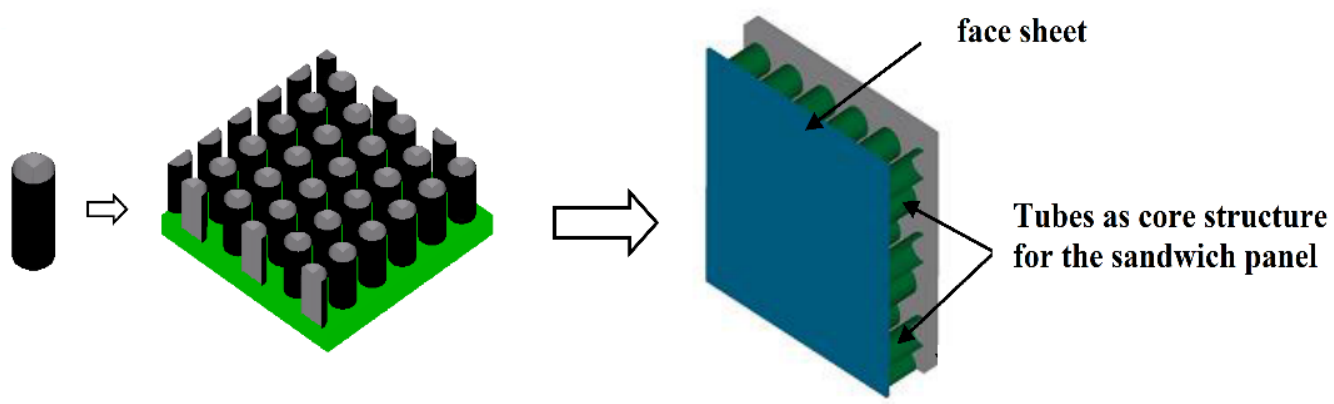

Figure 7. Example of tubular sandwich structure.

\subsubsection{Corrugated Core-Like Structures}

Corrugated cores in sandwich panels are easy to construct and have been shown to perform well under compression testing. Table 8 details a summary of some of the related applications of such sandwich structures. The typical applications reported in the literature are for low velocity impact (perforation), shock wave, and crashworthiness applications. For sandwich structure face sheets, typical materials used are either metals (stainless steel/aluminum) or fiber composites. For the core structure, the most common material used was metal followed by polymer. Some of the key findings are as follows:

- Corrugation buckling and fracture are the main failure mode.

- The corrugated core can be viewed as a subset of the origami core design. As such, the failure mechanism characteristics are similar to those of the origami cores. 
Table 7. Sandwich structure with tubular core.

\begin{tabular}{|c|c|c|c|}
\hline Sandwich Construction & Loading/Application & Summary of Findings & Reference \\
\hline $\begin{array}{l}\text { Typical thin-walled square lattice } \\
\text { truss tubes formed in a tubular } \\
\text { sandwich manner }\end{array}$ & $\begin{array}{c}\text { Compression test } \\
\text { (Crashworthiness-simulation) }\end{array}$ & $\begin{array}{c}\text { The sandwich wall has bending rigidity } \\
\text { which improves the EA through shortening } \\
\text { the wave length and improving the plastic } \\
\text { bending moment }\end{array}$ & [104] \\
\hline $\begin{array}{l}\text { Sandwich structure comprise of tubes as } \\
\text { core and thin face sheets riveted to the } \\
\text { tubes. Material used is aluminium }\end{array}$ & $\begin{array}{l}\text { Blast loading } \\
\text { (Blast-simulation) }\end{array}$ & $\begin{array}{l}\text { The effects of the spacing between the tubes } \\
\text { affects the plastic hinges formation and } \\
\text { interaction between the tubes. }\end{array}$ & [105] \\
\hline $\begin{array}{l}\text { Tubular composite structures made from } \\
\text { carbon fiber composite with/without } \\
\text { Nomex honeycomb sandwich core. }\end{array}$ & $\begin{array}{c}\text { Impact Testing } \\
\text { (Perforation-experiment) }\end{array}$ & $\begin{array}{c}\text { The core material in the sandwich tubes } \\
\text { absorbs more impact energy and resist } \\
\text { severe local damage formation. }\end{array}$ & [106] \\
\hline Aluminum foam sandwich tubes & $\begin{array}{l}\text { Compression test } \\
\text { (Crashworthiness-experiment) }\end{array}$ & $\begin{array}{c}\text { Better energy absorption characteristics } \\
\text { can be obtained by the proper thickness } \\
\text { of metal foam core }\end{array}$ & {$[107,108]$} \\
\hline $\begin{array}{l}\text { Sandwich panels made from aluminum } \\
\text { face sheets and honeycomb cores. Some } \\
\text { cores reinforced with aluminium tubes. }\end{array}$ & $\begin{array}{l}\text { Compression testing-drop weight } \\
\text { (crashworthiness-experiment) }\end{array}$ & $\begin{array}{l}\text { The tube structure in some of the } \\
\text { honeycomb cores exhibited higher and } \\
\text { uniform energy absorption. Such structures } \\
\text { had better impact resistance as well. }\end{array}$ & [56] \\
\hline $\begin{array}{l}\text { The tubes are made from carbon fiber } \\
\text { composite. The inner tube is filled with } \\
\text { composite sandwich panels made from } \\
\text { carbon fiber and Nomex honeycomb. }\end{array}$ & $\begin{array}{l}\text { Compression testing } \\
\text { (crashworthiness_experiment/simulation) }\end{array}$ & $\begin{array}{l}\text { The tubes filled with the composite } \\
\text { sandwich panels had better crash } \\
\text { parameter performance }\end{array}$ & [109] \\
\hline $\begin{array}{l}\text { The tubes are made from carbon fiber } \\
\text { composite. These tubes are inserted into } \\
\text { the center of the honeycomb. Four types } \\
\text { of honeycomb material was used. The face } \\
\text { sheet was made from carbon fiber. }\end{array}$ & $\begin{array}{l}\text { Compression testing } \\
\text { (crashworthiness-experiment/simulation) }\end{array}$ & $\begin{array}{l}\text { The tubes which were inserted into the } \\
\text { center of the honeycomb structure had much } \\
\text { better energy absorption capabilities. }\end{array}$ & [110] \\
\hline
\end{tabular}

Table 8. Sandwich structure with corrugated core.

\begin{tabular}{|c|c|c|c|}
\hline Sandwich Construction & Loading/Application & Summary of Findings & Reference \\
\hline $\begin{array}{l}\text { Kirigami modified corrugated core. } \\
\text { Bothe the core and sandwich plates are } \\
\text { made from aluminium. }\end{array}$ & $\begin{array}{l}\text { Impact Perforation and Compression } \\
\text { test by pendulum } \\
\text { (Blast-experiment and simulation) }\end{array}$ & $\begin{array}{c}\text { The sandwich made from Kirigami corrugated } \\
\text { core had superior impact resistance } \\
\text { when compared to panels with simple } \\
\text { corrugated core. }\end{array}$ & [111] \\
\hline $\begin{array}{l}\text { 3D printed sandwich panels where the } \\
\text { core is bi-directional corrugated design. } \\
\text { The material used was polycarbonate. }\end{array}$ & $\begin{array}{c}\text { Compression test } \\
\text { (Impact, Crashworthiness-experiment } \\
\text { and simulation) }\end{array}$ & $\begin{array}{l}\text { The sandwich structure with bi-directional } \\
\text { corrugated core is obviously superior to the } \\
\text { conventional sandwich structure with } \\
\text { single-directional corrugated core. }\end{array}$ & [112] \\
\hline $\begin{array}{l}\text { Entire sandwich panels made from steel. } \\
\text { The core is trapezoidal corrugation. }\end{array}$ & $\begin{array}{c}\text { Impact Testing } \\
\text { (Perforation-experiment and simulation) }\end{array}$ & $\begin{array}{c}\text { The corrugated core design provided good } \\
\text { shock absorption however; the performance } \\
\text { was enhanced by filling with sand (dependent } \\
\text { on density and stiffness of sand). }\end{array}$ & [113] \\
\hline $\begin{array}{l}\text { The sandwich panel (face sheets and } \\
\text { corrugated core) was constructed } \\
\text { from glass fiber reinforced } \\
\text { polypropylene prepreg }\end{array}$ & $\begin{array}{l}\text { Compression test } \\
\text { (Crashworthiness-experimental } \\
\text { and simulation) }\end{array}$ & $\begin{array}{l}\text { Number of layered cores play an important } \\
\text { role in the energy absorption capabilities. It } \\
\text { was found that the way the corrugated cores } \\
\text { are layered up affects the performance. }\end{array}$ & [114] \\
\hline $\begin{array}{l}\text { Curved sandwich panels-face sheets } \\
\text { and axial/circular corrugated core } \\
\text { made from carbon fiber composites. }\end{array}$ & $\begin{array}{l}\text { Low velocity impact test } \\
\text { (Blast/Impact-experiment/simulation) }\end{array}$ & $\begin{array}{c}\text { The axially corrugated sandwich } \\
\text { panels displayed good impact } \\
\text { resistance characteristics. }\end{array}$ & [115] \\
\hline $\begin{array}{l}\text { E-glass sandwich panels for face sheets } \\
\text { and corrugated cores: triangular, } \\
\text { trapezoidal, rectangular were used. } \\
\text { Some specimens had PVC foam filling. }\end{array}$ & $\begin{array}{l}\text { Compression testing } \\
\text { (crashworthiness-experiment) }\end{array}$ & $\begin{array}{l}\text { Corrugated cores have higher energy } \\
\text { absorption than just traditional foam filled } \\
\text { sandwich structures. The number of unit } \\
\text { cell/unit length and the corrugation angle } \\
\text { plays a crucial role in the energy absorption } \\
\text { performance. Plastic buckling of the } \\
\text { corrugated cell walls are the initial } \\
\text { failure modes observed. }\end{array}$ & [116] \\
\hline
\end{tabular}

\section{Discussion and Research Direction}

From the literature review presented above, it is obvious that sandwich structures are good candidates for energy absorption applications. The traditional panels made from foam and honeycomb cores are being challenged against newly architected cores. In principle, the failure mechanism of such sandwich structures play a crucial role in determining the energy absorption capabilities. As such, the usage of sandwich structures 
for energy absorption applications requires extensive design parametric studies to optimize the panel for a certain application, as shown from the literature review.

The work published thus far is scattered in terms of potential real-life application. It is not possible to support any sandwich structure design as the ultimate energy absorber design because a lot of material configurations, structure size, loading conditions, and structure geometry conditions were tested and investigated. It is an uphill task to normalize the findings of such works. Some of these have not been tested at different scales of size or different loading conditions (example strain rate sensitivity). In view of this, the future direction of sandwich structures for energy absorption should be as follows:

- The development of a more comprehensive experimental scheme that will allow for the performance evaluation of a particular sandwich structure design based on parametric study to understand the structure response from different scales of size and at different high strain dynamic events.

- This should be supported by numerical simulation to reduce cost and to expedite the understanding of the structure's response.

- The findings should be linked to the failure mechanism and used to develop a design map that allows to better understand the effect of selecting different parametric variables on the desired performance (to identify design rules).

- Similar approach should be conducted on different core design and material (including face sheets).

- $\quad$ Based on the extensive experimental supported by a numerical simulation scheme (as discussed previously), there will be a need to use artificial intelligence/data mining with topology optimization to design sandwich structure(s) for a particular application. Some of the recent works in using artificial intelligence in design can be found in the following works [117-121].

- Studies should also be performed to assess the effect of small damages on the crashworthiness or blast performance. Residual/minor indentation due to either manufacturing defects or human handling of the structure can affect the overall performance. Such work is yet to be reported within the scope of sandwich structures as energy absorbers.

- Issues related to manufacturing: The ease of fabrication, ease of maintenance, impact on environment, sustainability, scaling up (mass production), and life-cycle cost analysis are not well discussed. There is a need to map the overall sandwich structure performance with such indicators. This will help designers select the most appropriate sandwich structure design.

\section{Conclusions}

This review paper addresses the usage of sandwich structures for energy absorption applications. It was found that such sandwich structures are good candidates to be designed as energy absorbers. Depending on the type of loading conditions, it was observed that the failure mechanism of such structures is highly dependent on the core geometry and design variables, such as core thickness, cell thickness, face sheet thickness, type of material, etc. The review shows that the work in this area is vast and does not converge to any particular structure design. There is good potential in using sandwich structures, but these structures need to be designed in a more intelligent way to fully realize their potential. As such, the future direction of designing such structures is through the usage of artificial intelligence/data mining coupled with topology optimization.

Funding: This research received no external funding.

Institutional Review Board Statement: Not applicable.

Informed Consent Statement: Not applicable.

Data Availability Statement: Not applicable. 
Acknowledgments: The author would like to thank Qatar National Research Fund for supporting the APC for this manuscript.

Conflicts of Interest: The authors declare no conflict of interest.

\section{References}

1. Herrmann, C.; Dewulf, W.; Hauschild, M.; Kaluza, A.; Kara, S.; Skerlos, S. Life cycle engineering of lightweight structures. CIRP Ann. 2018, 67, 651-672. [CrossRef]

2. Tarlochan, F.; Samer, F.; Hamouda, A.M.S.; Ramesh, S.; Khalid, K. Design of thin wall structures for energy absorption applications: Enhancement of crashworthiness due to axial and oblique impact forces. Thin-Walled Struct. 2013, 71, 7-17. [CrossRef]

3. Mudassir, M.; Tarlochan, F.; Mansour, M.A. Nature-Inspired Cellular Structure Design for Electric Vehicle Battery Compartment: Application to Crashworthiness. Appl. Sci. 2020, 10, 4532. [CrossRef]

4. Alqwasmi, N.; Tarlochan, F.; Alkhatib, S.E. Study of mild steel sandwich structure energy absorption performance subjected to localized impulsive loading. Materials 2020, 13, 670. [CrossRef]

5. Alkhatib, S.E.; Tarlochan, F.; Eyvazian, A. Collapse behavior of thin-walled corrugated tapered tubes. Eng. Struct. 2017, 150, 674-692. [CrossRef]

6. Alkhatib, S.E.; Tarlochan, F.; Hashem, A.; Sassi, S. Collapse behavior of thin-walled corrugated tapered tubes under oblique impact. Thin-Walled Struct. 2018, 122, 510-528. [CrossRef]

7. Tarlochan, F.; Samer, F. Design of thin wall structures for energy absorption applications: Design for crash injuries mitigation using magnesium alloy. Int. J. Res. Eng. Technol. 2013, 2, 24-36.

8. Dastjerdi, A.A.; Shahsavari, H.; Eyvazian, A.; Tarlochan, F. Crushing analysis and multi-objective optimization of different length bi-thin walled cylindrical structures under axial impact loading. Eng. Optim. 2019, 51, 1884-1901. [CrossRef]

9. Alkhatib, S.E.; Matar, M.S.; Tarlochan, F.; Laban, O.; Mohamed, A.S.; Alqwasmi, N. Deformation modes and crashworthiness energy absorption of sinusoidally corrugated tubes manufactured by direct metal laser sintering. Eng. Struct. 2019, 201, 109838 [CrossRef]

10. Yan, L.L.; Yu, B.; Han, B.; Chen, C.Q.; Zhang, Q.C.; Lu, T.J. Compressive strength and energy absorption of sandwich panels with aluminum foam-filled corrugated cores. Compos. Sci. Technol. 2013, 86, 142-148. [CrossRef]

11. Wu, Q.; Ma, L.; Liu, Q.; Feng, L.; Wang, Z.; Ohrndorf, A.; Christ, H.J.; Xiong, J. Impact response and energy absorption of human skull cellular bones. J. Mech. Behav. Biomed. Mater. 2018, 81, 106-119. [CrossRef]

12. Tarlochan, F.; Hamouda, A.M.S.; Mahdi, E.; Sahari, B.B. Composite sandwich structures for crashworthiness applications. Proc. Inst. Mech. Eng. Part L J. Mater. Des. Appl. 2007, 221, 121-130. [CrossRef]

13. Gibson, L.J.; Ashby, M.F. Cellular Solids: Structure and Properties; Cambridge University Press: Cambridge, UK, 1999.

14. Yu, H.; Guo, Z.; Li, B.; Yao, G.; Luo, H.; Liu, Y. Research into the effect of cell diameter of aluminum foam on its compressive and energy absorption properties. Mater. Sci. Eng. A 2007, 454, 542-546. [CrossRef]

15. Zheng, J.; Qin, Q.; Wang, T. Impact plastic crushing and design of density-graded cellular materials. Mech. Mater. 2016, 94, 66-78. [CrossRef]

16. Zhou, J.; Guan, Z.; Cantwell, W. The impact response of graded foam sandwich structures. Compos. Struct. 2013, 97, 370-377. [CrossRef]

17. Wang, E.; Gardner, N.; Shukla, A. The blast resistance of sandwich composites with stepwise graded cores. Int. J. Solids Struct. 2009, 46, 3492-3502. [CrossRef]

18. Hoo Fatt, M.S.; Palla, L. Analytical modeling of composite sandwich panels under blast loads. J. Sandw. Struct. Mater. 2009, 11, 357-380. [CrossRef]

19. Gardner, N.; Wang, E.; Shukla, A. Performance of functionally graded sandwich composite beams under shock wave loading. Compos. Struct. 2012, 94, 1755-1770. [CrossRef]

20. Gupta, S.; Shukla, A. Blast performance of marine foam core sandwich composites at extreme temperatures. Exp. Mech. 2012, 52, 1521-1534. [CrossRef]

21. Tekalur, S.A.; Shukla, A.; Shivakumar, K. Blast resistance of polyurea based layered composite materials. Compos. Struct. 2008, 84, 271-281. [CrossRef]

22. Langdon, G.S.; von Klemperer, C.J.; Rowland, B.K.; Nurick, G.N. The response of sandwich structures with composite face sheets and polymer foam cores to air blast loading: Preliminary experiments. Eng. Struct. 2012, 36, 104-112. [CrossRef]

23. Kelly, M.; Arora, H.; Worley, A.; Kaye, M.; Linz, P.D.; Hooper, P.A.; Dear, J.P. Sandwich panel cores for blast applications: Materials and graded density. Exp. Mech. 2016, 56, 523-544. [CrossRef]

24. Andrews, E.W.; Moussa, N.A. Failure mode maps for composite sandwich panels subjected to air blast loading. Int. J. Impact Eng. 2009, 36, 418-425. [CrossRef]

25. Jackson, M.; Shukla, A. Performance of sandwich composites subjected to sequential impact and air blast loading. Compos. B Eng. 2011, 42, 155-166. [CrossRef]

26. Tekalur, S.A.; Bogdanovich, A.E.; Shukla, A. Shock loading response of sandwich panels with 3-D woven E-glass composite skins and stitched foam core. Compos. Sci. Technol. 2009, 69, 736-753. [CrossRef]

27. Arora, H.; Hooper, P.A.; Dear, J.P. Dynamic response of full-scale sandwich composite structures subject to air-blast loading Compos. A Appl. Sci. Manuf. 2011, 42, 1651-1662. [CrossRef] 
28. Arora, H.; Hooper, P.A.; Dear, J.P. The effects of air and underwater blast on composite sandwich panels and tubular laminate structures. Exp. Mech. 2012, 52, 59-81. [CrossRef]

29. Schiffer, A.; Tagarielli, V.L. Underwater blast loading of water-backed sandwich plates with elastic cores: Theoretical modelling and simulations. Int. J. Impact Eng. 2017, 102, 62-73. [CrossRef]

30. Avachat, S.; Zhou, M. Effect of facesheet thickness on dynamic response of composite sandwich plates to underwater impulsive loading. Exp. Mech. 2012, 52, 83-93. [CrossRef]

31. Wang, E.; Shukla, A. Blast performance of sandwich composites with in-plane compressive loading. Exp. Mech. 2012, 52, 49-58. [CrossRef]

32. Fatt, M.S.H.; Gao, Y.; Sirivolu, D. Foam-core, curved composite sandwich panels under blast. J. Sandw. Struct. Mater. 2013, 15, 261-291. [CrossRef]

33. Hoo Fatt, M.S.; Sirivolu, D. Blast response of double curvature, composite sandwich shallow shells. Eng. Struct. 2015, 100, 696-706. [CrossRef]

34. Gardner, N.; Gupta, S.; Shukla, A.; Nolet, S. Dynamic response of nano-scale core-shell rubber toughened sandwich composites: Dynamic response of CSR toughened sandwich composites. Strain 2014, 50, 501-516. [CrossRef]

35. Rolfe, E.; Quinn, R.; Sancho, A.; Kaboglu, C.; Johnson, A.; Liu, H.; Hooper, P.A.; Dear, J.P.; Arora, H. Blast resilience of composite sandwich panels with hybrid glass-fibre and carbon-fibre skins. Multiscale Multidiscip. Model. Exp. Des. 2018, 1, 197-210. [CrossRef]

36. Nasirzadeh, R.; Sabet, A.R. Study of foam density variations in composite sandwich panels under high velocity impact loading. Int. J. Impact Eng. 2014, 63, 129-139. [CrossRef]

37. Tarlochan, F.; Ramesh, S.; Harpreet, S. Advanced composite sandwich structure design for energy absorption applications: Blast protection and crashworthiness. Compos. Part B Eng. 2012, 43, 2198-2208. [CrossRef]

38. Tarlochan, F.; Ramesh, S. Composite sandwich structures with nested inserts for energy absorption application. Compos. Struct. 2012, 94, 904-916. [CrossRef]

39. Li, S.; Wang, Z.; Wu, G.; Zhao, L.; Li, X. Dynamic response of sandwich spherical shell with graded metallic foam cores subjected to blast loading. Compos. A Appl. Sci. Manuf. 2014, 56, 262-271. [CrossRef]

40. Jing, L.; Zhao, L. Blast resistance and energy absorption of sandwich panels with layered gradient metallic foam cores. J. Sandw. Struct. Mater. 2019, 21, 464-482. [CrossRef]

41. Huo, X.; Sun, G.; Zhang, H.; Lv, X.; Li, Q. Experimental study on low-velocity impact responses and residual properties of composite sandwiches with metallic foam core. Compos. Struct. 2019, 223, 110835. [CrossRef]

42. Jing, L.; Yang, F.; Zhao, L. Perforation resistance of sandwich panels with layered gradient metallic foam cores. Compos. Struct. 2017, 171, 217-226. [CrossRef]

43. Santosa, S.P.; ArifurRahman, F.; Izzudin, M.H.; Widagdo, D.; Gunawan, L. Response Analysis of Blast Impact Loading of Metal-foam Sandwich Panels. Procedia Eng. 2017, 173, 495-502. [CrossRef]

44. Sun, G.; Wang, E.; Zhang, J.; Li, S.; Zhang, Y.; Li, Q. Experimental study on the dynamic responses of foam sandwich panels with different face sheets and core gradients subjected to blast impulse. Int. J. Impact Eng. 2020, 135, 103327. [CrossRef]

45. Sun, G.; Wang, Z.; Yu, H.; Gong, Z.; Li, Q. Experimental and numerical investigation into the crashworthiness of metal-foamcomposite hybrid structures. Compos. Struct. 2019, 209, 535-547. [CrossRef]

46. Xu, P.; Ruan, G.; Shen, J.; Li, C.; Chen, Y. Optimization design and crash-worthiness analysis of tank made of aluminum foam sandwich. IOP Conf. Ser. Earth Environ. Sci. 2019, 233, 052021. [CrossRef]

47. Epasto, G.; Distefano, F.; Gu, L.; Mozafari, H.; Linul, E. Design and optimization of Metallic Foam Shell protective device against flying ballast impact damage in railway axles. Mater. Des. 2020, 196, 109120. [CrossRef]

48. Wang, E.; Li, Q.; Sun, G. Computational analysis and optimization of sandwich panels with homogeneous and graded foam cores for blast resistance. Thin-Walled Struct. 2020, 147, 106494. [CrossRef]

49. Dirgantara, T.; Jusuf, A.; Kurniati, E.O.; Gunawan, L.; Putra, I.S. Crashworthiness analysis of foam-filled square column considering strain rate effect of the foam. Thin-Walled Struct. 2018, 129, 365-380. [CrossRef]

50. Liu, X.R.; Tian, X.G.; Lu, T.J.; Liang, B. Sandwich plates with functionally graded metallic foam cores subjected to air blast loading. Int. J. Mech. Sci. 2014, 84, 61-72. [CrossRef]

51. Li, S.; Li, X.; Wang, Z.; Wu, G.; Lu, G.; Zhao, L. Sandwich panels with layered graded aluminum honeycomb cores under blast loading. Compos. Struct. 2017, 173, 242-254. [CrossRef]

52. Nurick, G.N.; Langdon, G.S.; Chi, Y.; Jacob, N. Behaviour of sandwich panels subjected to intense air blast-Part 1: Experiments. Compos. Struct. 2009, 91, 433-441. [CrossRef]

53. Karagiozova, D.; Nurick, G.N.; Langdon, G.S. Behaviour of sandwich panels subject to intense air blasts-Part 2: Numerical simulation. Compos. Struct. 2009, 91, 442-450. [CrossRef]

54. Theobald, M.D.; Langdon, G.S.; Nurick, G.N.; Pillay, S.; Heyns, A.; Merrett, R.P. Large inelastic response of unbonded metallic foam and honeycomb core sandwich panels to blast loading. Compos. Struct. 2010, 92, 2465-2475. [CrossRef]

55. Buitrago, B.L.; Santiuste, C.; Sánchez-Sáez, S.; Barbero, E.; Navarro, C. Modelling of composite sandwich structures with honeycomb core subjected to high-velocity impact. Compos. Struct. 2010, 92, 2090-2096. [CrossRef]

56. Zhang, Y.; Yan, L.; Zhang, C.; Guo, S. Low-velocity impact response of tube-reinforced honeycomb sandwich structure. Thin-Walled Struct. 2021, 158, 107188. [CrossRef] 
57. Xue, X.; Zhang, C.; Chen, W.; Wu, M.; Zhao, J. Study on the impact resistance of honeycomb sandwich structures under low-velocity/heavy mass. Compos. Struct. 2019, 226, 111223. [CrossRef]

58. Zhang, D.; Fei, Q.; Zhang, P. Drop-weight impact behavior of honeycomb sandwich panels under a spherical impactor. Compos. Struct. 2017, 168, 633-645. [CrossRef]

59. Tan, C.Y.; Akil, H.M. Impact response of fiber metal laminate sandwich composite structure with polypropylene honeycomb core. Compos. Part B Eng. 2012, 43, 1433-1438. [CrossRef]

60. Sun, G.; Chen, D.; Huo, X.; Zheng, G.; Li, Q. Experimental and numerical studies on indentation and perforation characteristics of honeycomb sandwich panels. Compos. Struct. 2018, 184, 110-124. [CrossRef]

61. Gunes, R.; Arslan, K. Development of numerical realistic model for predicting low-velocity impact response of aluminium honeycomb sandwich structures. J. Sandw. Struct. Mater. 2016, 18, 95-112. [CrossRef]

62. Sun, G.; Chen, D.; Wang, H.; Hazell, P.J.; Li, Q. High-velocity impact behaviour of aluminium honeycomb sandwich panels with different structural configurations. Int. J. Impact Eng. 2018, 122, 119-136. [CrossRef]

63. He, W.; Yao, L.; Meng, X.; Sun, G.; Xie, D.; Liu, J. Effect of structural parameters on low-velocity impact behavior of aluminum honeycomb sandwich structures with CFRP face sheets. Thin-Walled Struct. 2019, 137, 411-432. [CrossRef]

64. Han, B.; Qin, K.; Yu, B.; Wang, B.; Zhang, Q.; Lu, T.J. Honeycomb-corrugation hybrid as a novel sandwich core for significantly enhanced compressive performance. Mater. Des. 2016, 93, 271-282. [CrossRef]

65. Sun, Z.; Shi, S.; Guo, X.; Hu, X.; Chen, H. On compressive properties of composite sandwich structures with grid reinforced honeycomb core. Compos. Part B Eng. 2016, 94, 245-252. [CrossRef]

66. Roudbeneh, F.H.; Liaghat, G.; Sabouri, H.; Hadavinia, H. High-velocity impact loading in honeycomb sandwich panels reinforced with polymer foam: A numerical approach study. Iran Polym J. 2020, 29, 707-721. [CrossRef]

67. Ha, N.S.; Lu, G.; Xiang, X. Energy absorption of a bio-inspired honeycomb sandwich panel. J. Mater. Sci. 2019, 54, 6286-6300. [CrossRef]

68. Zhang, G.; Wang, B.; Ma, L.; Wu, L.; Pan, S.; Yang, J. Energy absorption and low velocity impact response of polyurethane foam filled pyramidal lattice core sandwich panels. Compos. Struct. 2014, 108, 304-310. [CrossRef]

69. Cui, X.; Zhao, L.; Wang, Z.; Zhao, H.; Fang, D. Dynamic response of metallic lattice sandwich structures to impulsive loading. Int. J. Impact Eng. 2012, 43, 1-5. [CrossRef]

70. Huang, W.; Fan, Z.; Zhang, W.; Liu, J.; Zhou, W. Impulsive response of composite sandwich structure with tetrahedral truss core. Compos. Sci. Technol. 2019, 176, 17-28. [CrossRef]

71. Yungwirth, C.J.; Radford, D.D.; Aronson, M.; Wadley, H.N. Experiment assessment of the ballistic response of composite pyramidal lattice truss structures. Compos. Part B Eng. 2008, 39, 556-569. [CrossRef]

72. Liu, J.; Liu, J.; Mei, J.; Huang, W. Investigation on manufacturing and mechanical behavior of all-composite sandwich structure with Y-shaped cores. Compos. Sci. Technol. 2018, 159, 87-102. [CrossRef]

73. Zhang, G.; Wang, B.; Ma, L.; Xiong, J.; Wu, L. Response of sandwich structures with pyramidal truss cores under the compression and impact loading. Compos. Struct. 2013, 100, 451-463. [CrossRef]

74. Feng, L.J.; Wei, G.T.; Yu, G.C.; Wu, L.Z. Underwater blast behaviors of enhanced lattice truss sandwich panels. Int. J. Mech. Sci. 2019, 150, 238-246. [CrossRef]

75. Dharmasena, K.P.; Wadley, H.N.; Williams, K.; Xue, Z.; Hutchinson, J.W. Response of metallic pyramidal lattice core sandwich panels to high intensity impulsive loading in air. Int. J. Impact Eng. 2011, 38, 275-289. [CrossRef]

76. Li, J.; Qin, Q.; Zhang, J. Internal blast resistance of sandwich cylinder with lattice cores. Int. J. Mech. Sci. 2021, 191, 106107. [CrossRef]

77. Xue, B.; Peng, Y.; Ren, S.; Liu, N.; Zhang, Q. Investigation of impact resistance performance of pyramid lattice sandwich structure based on SPH-FEM. Compos. Struct. 2021, 261, 113561. [CrossRef]

78. Gu, Z.P.; Wu, X.Q.; Li, Q.M.; Yin, Q.Y.; Huang, C.G. Dynamic compressive behaviour of sandwich panels with lattice truss core filled by shear thickening fluid. Int. J. Impact Eng. 2020, 143, 103616. [CrossRef]

79. Beharic, A.; Egui, R.R.; Yang, L. Drop-weight impact characteristics of additively manufactured sandwich structures with different cellular designs. Mater. Des. 2018, 145, 122-134. [CrossRef]

80. Zhang, J.; Lu, G.; Zhang, Y.; You, Z. A study on ballistic performance of origami sandwich panels. Int. J. Impact Eng. 2021, 156, 103925. [CrossRef]

81. Chen, Z.; Wu, T.; Nian, G.; Shan, Y.; Liang, X.; Jiang, H.; Qu, S. Ron Resch Origami Pattern Inspired Energy Absorption Structures J. Appl. Mech. 2019, 86, 011005. [CrossRef]

82. Zang, S.; Zhou, X.; Wang, H.; You, Z. Foldcores made of thermoplastic materials: Experimental study and finite element analysis. Thin-Walled Struct. 2016, 100, 170-179. [CrossRef]

83. Schenk, M.; Guest, S.D.; McShane, G.J. Novel stacked folded cores for blast-resistant sandwich beams. Int. J. Solids Struct. 2014, 51, 4196-4214. [CrossRef]

84. Pydah, A.; Batra, R.C. Crush dynamics and transient deformations of elastic-plastic Miuraori core sandwich plates. Thin-Walled Struct. 2017, 115, 311-322. [CrossRef]

85. Kilchert, S.; Johnson, A.F.; Voggenreiter, H. Modelling the impact behaviour of sandwich structures with folded composite cores. Compos. Part A Appl. Sci. Manuf. 2014, 57, 16-26. [CrossRef] 
86. Qi, J.; Li, C.; Tie, Y.; Zheng, Y.; Duan, Y. Energy absorption characteristics of origami-inspired honeycomb sandwich structures under low-velocity impact loading. Mater. Des. 2021, 207, 109837. [CrossRef]

87. Ma, J.; Dai, H.; Chai, S.; Chen, Y. Energy absorption of sandwich structures with a kirigami-inspired pyramid foldcore under quasi-static compression and shear. Mater. Des. 2021, 206, 109808. [CrossRef]

88. Zhang, P.; Li, X.; Wang, Z.; Zhao, L.; Yan, X. Dynamic blast loading response of sandwich beam with origami-inspired core. Results Phys. 2018, 10, 946-955. [CrossRef]

89. Sarvestani, H.Y.; Akbarzadeh, A.H.; Niknam, H.; Hermenean, K. 3D printed architected polymeric sandwich panels: Energy absorption and structural performance. Compos. Struct. 2018, 200, 886-909. [CrossRef]

90. Yang, S.; Qi, C.; Wang, D.; Gao, R.; Hu, H.; Shu, J. A Comparative Study of Ballistic Resistance of Sandwich Panels with Aluminum Foam and Auxetic Honeycomb Cores. Adv. Mech. Eng. 2013, 589216. [CrossRef]

91. Imbalzano, G.; Tran, P.; Ngo, T.D.; Lee, P.V. A numerical study of auxetic composite panels under blast loadings. Compos. Struct. 2016, 135, 339-352. [CrossRef]

92. Imbalzano, G.; Tran, P.; Ngo, T.D.; Lee, P.V. Three-dimensional modelling of auxetic sandwich panels for localised impact resistance. J. Sandw. Struct. Mater. 2017, 19, 291-316. [CrossRef]

93. Imbalzano, G.; Linforth, S.; Ngo, T.D.; Lee PV, S.; Tran, P. Blast resistance of auxetic and honeycomb sandwich panels: Comparisons and parametric designs. Compos. Struct. 2018, 183, 242-261. [CrossRef]

94. Sarvestani, H.Y.; Akbarzadeh, A.H.; Mirbolghasemi, A.; Hermenean, K. 3D printed meta-sandwich structures: Failure mechanism, energy absorption and multi-hit capability. Mater. Des. 2018, 160, 179-193. [CrossRef]

95. Madke, R.R.; Chowdhury, R. Anti-impact behavior of auxetic sandwich structure with braided face sheets and 3D re-entrant cores. Compos. Struct. 2020, 236, 111838. [CrossRef]

96. Hou, S.; Li, T.; Jia, Z.; Wang, L. Mechanical properties of sandwich composites with 3d-printed auxetic and non-auxetic lattice cores under low velocity impact. Mater. Des. 2018, 160, 1305-1321. [CrossRef]

97. Qi, C.; Remennikov, A.; Pei, L.-Z.; Yang, S.; Yu, Z.-H.; Ngo, T. Impact and close-in blast response of auxetic honeycomb-cored sandwich panels: Experimental tests and numerical simulations. Compos. Struct. 2017, 180, 161-178. [CrossRef]

98. Qi, C.; Pei, L.-Z.; Remennikov, A.; Yang, S.; Liu, J.; Wang, J.-S.; Liao, X.-W. Parametric study and optimization of the protect system containing a re-entrant hexagon cored sandwich panel under blast impact. Compos. Struct. 2020, 252, 112711. [CrossRef]

99. Novak, N.; Starčevič, L.; Vesenjak, M.; Ren, Z. Blast response study of the sandwich composite panels with 3D chiral auxetic core. Compos. Struct. 2019, 2019, 167-178. [CrossRef]

100. Jin, X.; Wang, Z.; Ning, J.; Xiao, G.; Liu, E.; Shu, X. Dynamic response of sandwich structures with graded auxetic honeycomb cores under blast loading. Compos. Part B Eng. 2016, 106, 206-217. [CrossRef]

101. Chen, G.; Cheng, Y.; Zhang, P.; Cai, S.; Liu, J. Blast resistance of metallic double arrowhead honeycomb sandwich panels with different core configurations under the paper tube-guided air blast loading. Int. J. Mech. Sci. 2021, 210, 106457. [CrossRef]

102. Usta, F.; Türkmen, H.S.; Scarpa, F. Low-velocity impact resistance of composite sandwich panels with various types of auxetic and non-auxetic core structures. Thin-Walled Struct. 2021, 163, 107738. [CrossRef]

103. Wang, Y.; Zhao, W.; Zhou, G.; Wang, C. Analysis and parametric optimization of a novel sandwich panel with double-V auxetic structure core under air blast loading. Int. J. Mech. Sci. 2018, 142-143, 245-254. [CrossRef]

104. Luo, Y.; Fan, H. Energy absorbing ability of rectangular self-similar multi-cell sandwich-walled tubular structures. Thin-Walled Struct. 2018, 124, 88-97. [CrossRef]

105. Wang, C.; Xu, B.; Yuen SC, K. Numerical analysis of cladding sandwich panels with tubular cores subjected to uniform blast load. Int. J. Impact Eng. 2019, 133, 103345. [CrossRef]

106. Zhang, C.; Tan, K.T. Low-velocity impact response and compression after impact behavior of tubular composite sandwich structures. Compos. Part B Eng. 2020, 193, 108026. [CrossRef]

107. Zhang, J.; Ye, Y.; Li, J.; Zhu, Y.; Yuan, H.; Qin, Q.; Zhao, M. Dynamic collapse of circular metal foam core sandwich tubes in splitting and curling mode. Thin-Walled Struct. 2021, 161, 107464. [CrossRef]

108. Zhang, J.; Ye, Y.; Zhu, Y.; Yuan, H.; Qin, Q.; Wang, T. On axial splitting and curling behaviour of circular sandwich metal tubes with metal foam core. Int. J. Solids Struct. 2020, 202, 111-125. [CrossRef]

109. Chen, Y.; Ye, L.; Fu, K. Progressive failure of CFRP tubes reinforced with composite sandwich panels: Numerical analysis and energy absorption. Compos. Struct. 2021, 263, 113674. [CrossRef]

110. Yan, L.; Zhu, K.; Chen, N.; Zheng, X.; Quaresimin, M. Energy-absorption characteristics of tube-reinforced absorbent honeycomb sandwich structure. Compos. Struct. 2021, 255, 112946. [CrossRef]

111. Li, Z.; Yang, Q.; Chen, W.; Hao, H.; Matenga, C.; Huang, Z.; Fang, R. Impact response of a novel sandwich structure with Kirigami modified corrugated core. Int. J. Impact Eng. 2021, 156, 103953. [CrossRef]

112. Ge, L.; Zheng, H.; Li, H.; Liu, B.; Su, H.; Fang, D. Compression behavior of a novel sandwich structure with bi-directional corrugated core. Thin-Walled Struct. 2021, 161, 107413. [CrossRef]

113. Yu, R.-P.; Wang, X.; Zhang, Q.-C.; Li, L.; He, S.-Y.; Han, B.; Ni, C.-Y.; Zhao, Z.-Y.; Lu, T.J. Effects of sand filling on the dynamic response of corrugated core sandwich beams under foam projectile impact. Compos. Part B Eng. 2020, 197, 108135. [CrossRef]

114. Chen, L.; Peng, S.; Liu, J.; Liu, H.; Chen, L.; Du, B.; Li, W.; Fang, D. Compressive response of multi-layered thermoplastic composite corrugated sandwich panels: Modelling and experiments. Compos. Part B Eng. 2020, 189, 107899. [CrossRef] 
115. Yang, J.-S.; Zhang, W.-M.; Yang, F.; Chen, S.-Y.; Schmidt, R.; Schröder, K.-U.; Ma, L.; Wu, L.-Z. Low velocity impact behavior of carbon fibre composite curved corrugated sandwich shells. Compos. Struct. 2020, 238, 112027. [CrossRef]

116. Taghizadeh, S.A.; Farrokhabadi, A.; Liaghat, G.; Pedram, E.; Malekinejad, H.; Mohammadi, S.F.; Ahmadi, H. Characterization of compressive behavior of PVC foam infilled composite sandwich panels with different corrugated core shapes. Thin-Walled Struct. 2019, 135, 160-172. [CrossRef]

117. Du, X. A Data Mining Methodology for Vehicle Crashworthiness Design. Ph.D. Thesis, Embry-Riddle Aeronautical University, Daytona Beach, FL, USA, 2019.

118. Du, X.; Xu, H.; Zhu, F. A data mining method for structure design with uncertainty in design variables. Comput. Struct. 2021, 244, 106457. [CrossRef]

119. He, C.; Li, Z.; Wang, S.; Liu, D. A systematic data-mining-based methodology for product family design and product configuration. Adv. Eng. Inform. 2021, 48, 101302. [CrossRef]

120. Lu, Y.; Tong, L. Concurrent topology optimization of cellular structures and anisotropic materials. Comput. Struct. 2021, 255, 106624. [CrossRef]

121. Tran, P.; Wu, C.; Saleh, M.; Neto, L.B.; Nguyen-Xuan, H.; Ferreira, A.J.M. Composite structures subjected to underwater explosive loadings: A comprehensive review. Compos. Struct. 2021, 263, 113684. [CrossRef] 